\title{
THEN AND NOW: UNDERSTANDING CHANGE ON AN AGRICULTURAL LANDSCAPE
}

\author{
By
}

Alexander Pardy

B.Sc. Hons. Environmental Science with Thesis, University of Windsor 2017

\author{
A thesis presented to Ryerson University \\ in partial fulfilment of the requirements \\ for the degree of \\ Master of Spatial Analysis \\ in the program of \\ Spatial Analysis
}

Toronto, Ontario, Canada, 2019

(C) Alexander Pardy, 2019 


\section{AUTHOR'S DECLARATION FOR ELECTRONIC SUBMISSION OF A THESIS}

I hereby declare that I am the sole author of this thesis. This is a true copy of the thesis, including any required final revisions, as accepted by my examiners.

I authorize Ryerson University to lend this thesis to other institutions or individuals for the purpose of scholarly research.

I further authorize Ryerson University to reproduce this thesis by photocopying or by other means, in total or in part, at the request of other institutions or individuals for the purpose of scholarly research.

I understand that my thesis may be made electronically available to the public. 
Then and Now: Understanding Change on an Agricultural Landscape, M.S.A., 2019, Alexander Pardy, Spatial Analysis, Ryerson University

\begin{abstract}
$\underline{\text { Abstract }}$
Freshwater eutrophication typically driven by non-point source phosphorus pollution is one of the worlds' most prevalent and vexing environmental problems with the Laurentian Great Lakes on the Canada - United States border. During 1975 - 1977, the Pollution from Land Use Activities Reference Group examined eleven agricultural watersheds in order to investigate the impacts of land use activities on surface water quality. This study examined how agricultural land use and management has transformed in two watersheds, Nissouri Creek and Big Creek. The goal of this study was to quantify the phosphorus mass balance change within the watersheds. During 2015 2019 land use and management practices survey data was collected. Results of this study showed Nissouri Creek is now depleting -2.19 kilograms of phosphorus per hectare of agricultural land, while Big Creek is still accumulating 4.77 kilograms of phosphorus per hectare of agricultural land. This study can guide efforts to limit the long-term losses of phosphorus in the Laurentian Great Lakes and elsewhere.
\end{abstract}




\section{$\underline{\text { Acknowledgements }}$}

To my supervisor, Dr. Christopher Wellen, I would like to express my sincere gratitude to you, for providing your invaluable expertise and time with this thesis and answering the numerous questions I may have asked. I thank everyone in the Land and Water Resources group for the stimulating discussion and helping me to process my ideas to paper. I would like to thank Dr. Claire Oswald and Dr. David Atkinson for taking the time to be co-readers of my thesis. I would also like to thank Dr. Claus Rinner for being the chair of my defense committee. Last but not least, I would like to thank my parents and my brother for always supporting me with my academic studies. 


\section{Table of Contents}

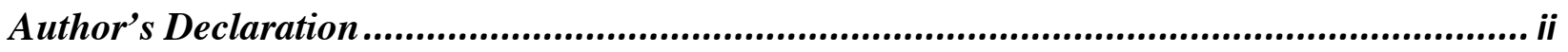

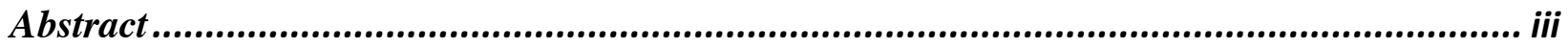

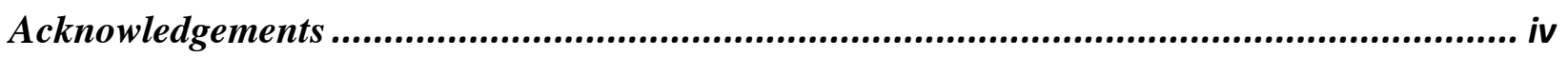

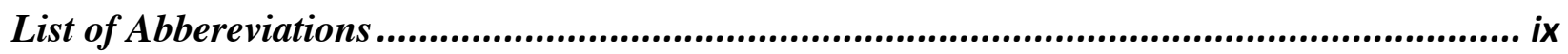

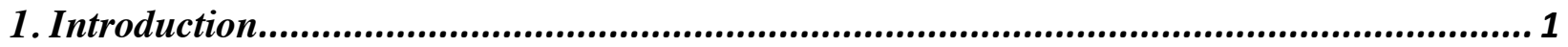

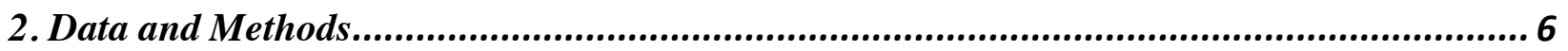

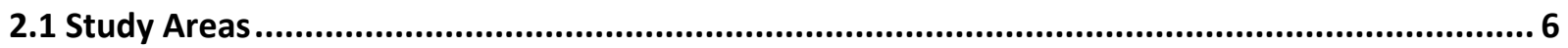

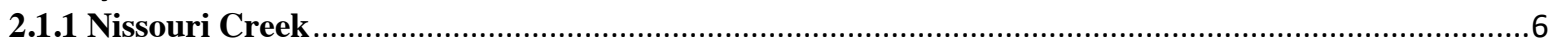

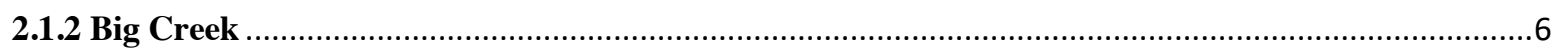

2.2 Historical and Present-Day Agricultural Land Use and Management Data .................................. 7

2.3 Land Use ......................................................................................................................... 9

2.4 Fertilizer Application ............................................................................................................... 10

2.5 Livestock Counts and Manure Amounts ............................................................................. 10

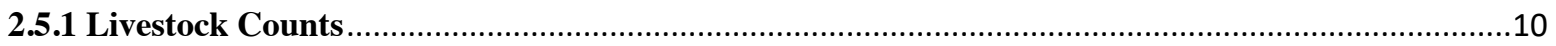

2.5.2 Manure Amounts and Phosphorus Content ……………………………………………………11

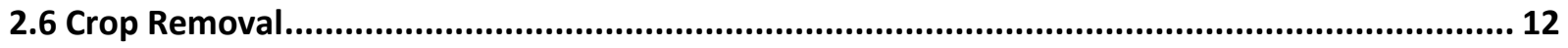

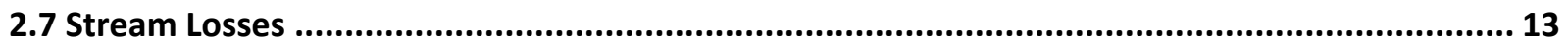

2.8 Quality Assurance and Quality Check ................................................................................. 14

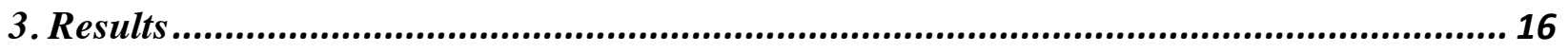

3.1 Land Use and Management Practices ..................................................................................... 16

3.2 Fertilizer Application ...................................................................................................... 17

3.3 Livestock Counts and Manure Amounts .................................................................................... 18

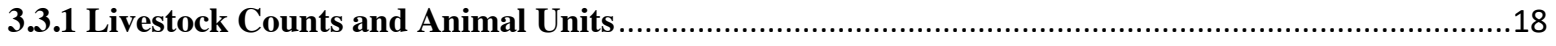

3.3.2 Manure Amount and Phosphorus Content ……………………………………………………...19

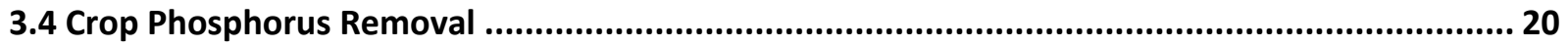

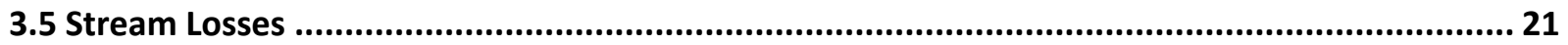

3.6 Overall P Balance ………............................................................................................................ 21

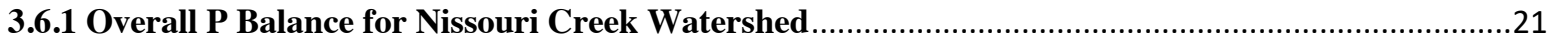

3.6.2 Overall P Balance for the Big Creek Watershed ……………………………………………….....22

3.7 Quality Assurance and Quality Check ...................................................................................... 24

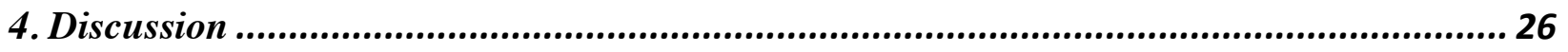

4.1 P Balance Agreement to Other Studies ............................................................................... 27

4.2 P Balance Components.......................................................................................................... 29

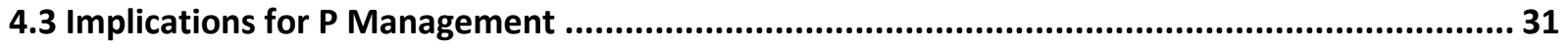




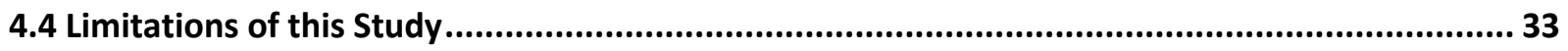

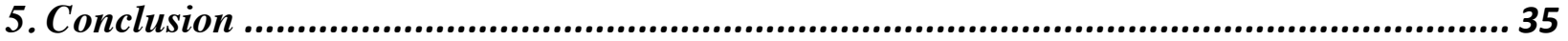

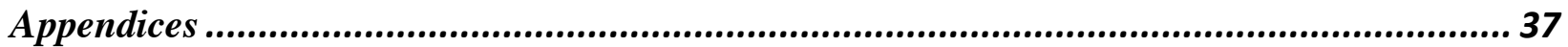

Appendix A. AGRI-Model Survey Response Sheets................................................................ 37

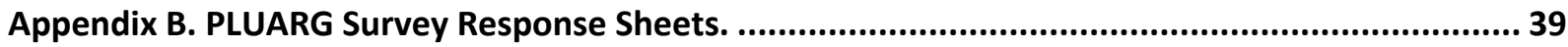

Appendix C. Supplementary Livestock Count and Manure Tables................................................. 43

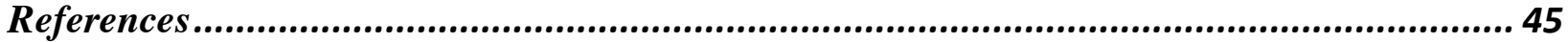




\section{List of Tables}

Table 1. The average $\mathrm{kg}$ of $\mathrm{P}$ removed per acre of a specific crop and $95 \%$ confidence intervals are shown.....

Table 2. Fertilizer P Application in Big Creek and Nissouri Creek Watersheds. Fertilizer application is shown as kilograms of fertilizer $\mathrm{P}$ per hectare of each specific agricultural crop grown. 95\% confidence intervals are shown in brackets for the present day.

Table 3. Calculated manure application rates shown as $\mathrm{kgP}_{\text {agha }}{ }^{-1}$ for both the Nissouri Creek and Big Creek watersheds, 95\% confidence intervals are shown in brackets.............................20 Table 4. The kg of P removed per crop hectare in both Big Creek and Nissouri Creek during the 1974-1976 time period and for the 2015-2018 time period. 95\% confidence intervals are shown in brackets for the present day. ${ }^{*}$ Legumes and soybeans were not grown in Nissouri Creek

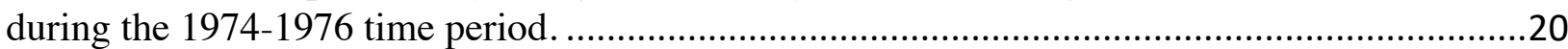
Table 5. The TP loadings for both Nissouri Creek and Big Creek watersheds, between the 1970's and the 2010's. 95\% confidence intervals are shown in brackets.

Table 6. Mean total value and error propagation results are shown for both Big Creek and Nissouri Creek for the 2015 - 2018 time period....................................................................... Table 7. Comparing other P balance studies with the Big Creek and Nissouri Creek Watersheds. Organized by authors, spatial scale, time periods, balance and units for both the beginning and ending time periods of the respective studies, and the net change in the balance .28 


\section{List of Figures}

Figure 1. The locations and shape of the Big Creek and Nissouri Creek Watersheds located in the larger Upper Thames and Lower Thames Watersheds in Southern Ontario. Hydrologic Soil Groups are also shown. Streams, Hydrologic Soil Groups, and Great Lakes shapefiles provided by the Ontario Ministry of Natural Resources............................................................................5 Figure 2. Coloured field by field crop map for the Nissouri watershed in 1974, this map allows us to see which field grew what crops for the specific year within the watershed. Small Grains Orange, Corn - Yellow, Soybeans - Purple, Pasture and Meadow - Green, Forest and

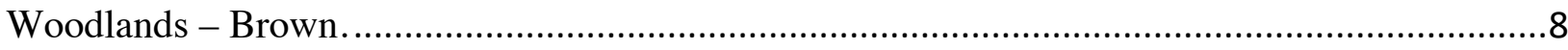

Figure 3. A typical poultry barn in Southern Ontario...............................................................

Figure 4. A typical dairy barn in Southern Ontario.................................................................

Figure 5. The differences in crop types between the Big Creek and Nissouri Creek Watersheds comparing the years 1975 - 1976 and 2015 - 2018 ............................................................17 Figure 6. The proportion of animal units in each watershed during the 1974-1975 time period as well as for the 2015-2018 time period. .19 Figure 7. Nissouri Creek overall P balance, with each P addition and removal shown for the 1974-1976 and 2015- 2018 time periods. Standard Error Bars are shown for the 2015-2018 data.

Figure 8. Big Creek overall $\mathrm{P}$ balance, with each $\mathrm{P}$ addition and removal shown for the 19741976 and 2015-2018 time periods. Standard Error Bars are shown for the 2015 - 2018 data......23 


\section{LIST OF ABBREVIATIONS}

AAFC - Agriculture and Agri-Food Canada

DRP - Dissolved Reactive Phosphorus

GLWQA - Great lakes Water Quality Agreement

IJC - International Joint Commission

MECP - Ontario Ministry of the Environment, Conservation and Parks.

MOECC - Ontario Ministry of the Environment and Climate Change

NPS - Non-Point Source

OMAFRA - Ontario Ministry of Agriculture, Farming, and Rural Affairs

P - Phosphorus

PLUARG - Pollution from Land Use Activities Reference Group

TP - Total Phosphorus

WLEB - Western Lake Erie Basin 


\section{Introduction}

Great Lakes water quality has always been a concern for both Canada and the United States. The emergence of dead zones and algal blooms in Lake Erie and other Great Lakes in the 1960's led the Canadian and the United States Governments to sign the Great Lakes Water Quality Agreement (GLWQA) on April 15, 1972 (GLWQA, 1972). The agreement requested the International Joint Commission (IJC) to investigate pollution of the boundary waters of the Great Lakes system from agricultural, forestry and other land use activities (GLWQA, 1972). The IJC established the Pollution from Land Use Activities Reference Group (PLUARG) to lead the investigation on behalf of the IJC. PLUARG had 3 main objectives: (1) To examine the magnitude of non-point source loading in agricultural, urban, and forested watersheds. (2) Develop relationships between land use, features of the landscape and nutrient loading. (3) Develop recommendations to reduce nutrient loads, if the loadings were found to be significant (PLUARG, 1974). The PLUARG group selected 11 small $\left(\sim 20-70 \mathrm{~km}^{2}\right)$ agricultural watersheds in different areas across Southern Ontario, to best represent the entirety of Southern Ontario agriculture. PLUARG discovered that land use and watershed characteristics could be used to predict nutrient loadings, $\sim 80 \%$ of variation in nitrogen and phosphorus (P) loadings are explained by the percentage of clay and percentage of crops (PLUARG, 1978). Algal blooms were mitigated in the 1970 's by the control of point sources, with Lake Erie responding quickly by a measurable decrease in total phosphorus (TP) concentrations (Dolan, 1993; Scavia et al., 2014). With the reemergence of algal blooms in Lake Erie in the mid 1990's and worsening in the early 2010's (Scavia et al., 2014) there was renewed interest in the relationship between land use and nutrient losses. It is known that the overall P loading has remained under the GLWQA target of 11,000 metric tons of P for most years since the 1980's (Obenour et al., 2014; Scavia et al., 2014). The 
amount of dissolved reactive P (DRP) loadings from the Maumee River and Sandusky River in Ohio has increased dramatically between the years of $1982-2007$ (Baker et al., 2014). DRP is the highest bioavailable form of $\mathrm{P}$ that supports algal growth, and is essentially $100 \%$ bioavailable (Sonzogni et al., 1982). There are the previously cited studies looking at Ohio loadings to Lake Erie and the Great Lakes, but there is little research on the Canadian side of Lake Erie.

In 2013, the province of Ontario through the Ministry of the Environment and Climate Change (MOECC), now the Ministry of the Environment, Conservation and Parks (MECP); launched the Multi-Watershed Nutrient Study (MWNS). The MWNS study is examining how agricultural land management and features of the landscape relate to nutrient losses in agricultural dominated watersheds in the Great Lakes Basin (Mohamed, n.d.). The MECP objective is to revisit some of the goals of the PLUARG study for a "then and now" analysis.

The MWNS selected eleven headwater sentinel agricultural watersheds in the basins of Lakes Erie, Ontario and Huron to study. The selected watersheds provide a wide range of different agricultural areas in Southern Ontario with differences in total $\mathrm{P}$ application, runoff amounts, and P balances (Rosamond et al., 2018). Variability between the eleven selected agricultural watersheds ranged in differences in soil $\mathrm{P}, \mathrm{P}$ inputs, and $\mathrm{P}$ transport.

The PLUARG studies discovered that among the eleven watersheds studied the soil clay content and the percent of land that was row cropped was the most important factor in determining phosphorus loadings (Miller et al., 1982). Stream water $\mathrm{P}$ was highest in watersheds with high fertilizer inputs, widespread tile drainage, and a predominant corn crop.

Presently the MECP conducts water monitoring in the eleven selected watersheds for the MWNS study and across the province through the Provincial Water Quality Monitoring Network. Chambers et al. (2008) looked at monthly Provincial Water Quality Monitoring Network samples 
from 1995 - 2005 to examine the relationship between land use and surface water concentrations of TP, finding that there was a positive correlation with the percentage of row cropped land in a watershed and the amount of TP in the surface water of streams. Richards et al. (2002) examined two Ohio watersheds, looking at the changes in land use from 1975 - 1995 such as farm size, cropping practices, tillage practices, and fertilizer amounts. The study found that TP amounts in the stream waters have actually decreased over the 21-year study period. The study relates these changes to changes in agricultural best management practices. The PLUARG study produced comprehensive water quality, and land use observations, but it was a short-term duration and only provided a snapshot of the time frame when the study was completed. There have been no recent studies in Canada like the PLUARG study which makes it difficult to compare the phosphorus loadings, land use changes, and the increase of eutrophication in Lake Erie without a comprehensive study of the current relationships between agricultural land use and $\mathrm{P}$ entering the Great Lakes. The PLUARG study is useful to use as a baseline to compare with the current land use trends.

Agricultural producers apply P inputs to soils in the form of fertilizer and manure to support optimum growth of crops, and to replace the phosphorus removed with harvesting crops. Not all of the $\mathrm{P}$ is removed from the agricultural area with the harvest (Powers et al., 2016). Frequently the amount of $\mathrm{P}$ leaving a field is less than the amount of $\mathrm{P}$ that has been added to the field. There could be crop residue left in fields, and instances where the amount of $\mathrm{P}$ applied exceeds crop removal. An example of this would be where manure is added to supplement nitrogen requirements for a crop. Increased soil $\mathrm{P}$ is one of several factors influencing loss of $\mathrm{P}$ to surface waters (Bruulsema et al., 2011). Previous research has shown the risk of $\mathrm{P}$ transport from land to water increases with higher soil test P levels (Sharpley, 1995; Howard et al., 2006). Reductions 
in TP and sediment loading from 1975 to 2004 has improved water quality in Lake Erie tributaries, reflecting a successful change in agricultural practices (Richards et al. 2009). Much of the surplus P applied before 1990 has likely contributed to a buildup in soil P fertility (Bast et al. 2009; Bruulsema et al., 2011). Looking at historical trends of an agricultural P mass balance serves as an important performance indicator for $\mathrm{P}$ management, reflecting both economic and environmental aspects of sustainability (Bast et al. 2009; Bruulsema et al., 2011; Joosse and Baker 2011).

This study analyzed two previously studied Ontario agricultural watersheds to compare the land use changes within the watershed and conduct a $\mathrm{P}$ balance comparing the trends of $\mathrm{P}$ between the 1970's and the 2010's. There has not been a P balance study completed on such a fine spatial scale on the Canadian side of the Great Lakes. This P balance study will state how much P is being lost to the streams, in different regions and cropping systems, and how much excess P might be driving these processes.

The Nissouri Creek and Big Creek watersheds were chosen for this study. These watersheds (Figure 1) were chosen because they were previously studied by PLUARG. The watersheds also provide a detailed representation of Southern Ontario agricultural watersheds, with differences in crops, variation in the amount of livestock, and both watersheds flow into the Thames River which drains into Lake St. Clair and in turn to Lake Erie. The Thames River is a priority watershed for the Western Lake Erie Basin (WLEB) due to the large P load that it releases into the Huron Erie Corridor. A goal in a 40\% reduction in the annual TP and DRP from the spring 2008 loads was established by the Great Lakes Water Quality Agreement Nutrients Annex Subcommittee (GLWQA Nutrient Annex Subcommittee, 2015). 


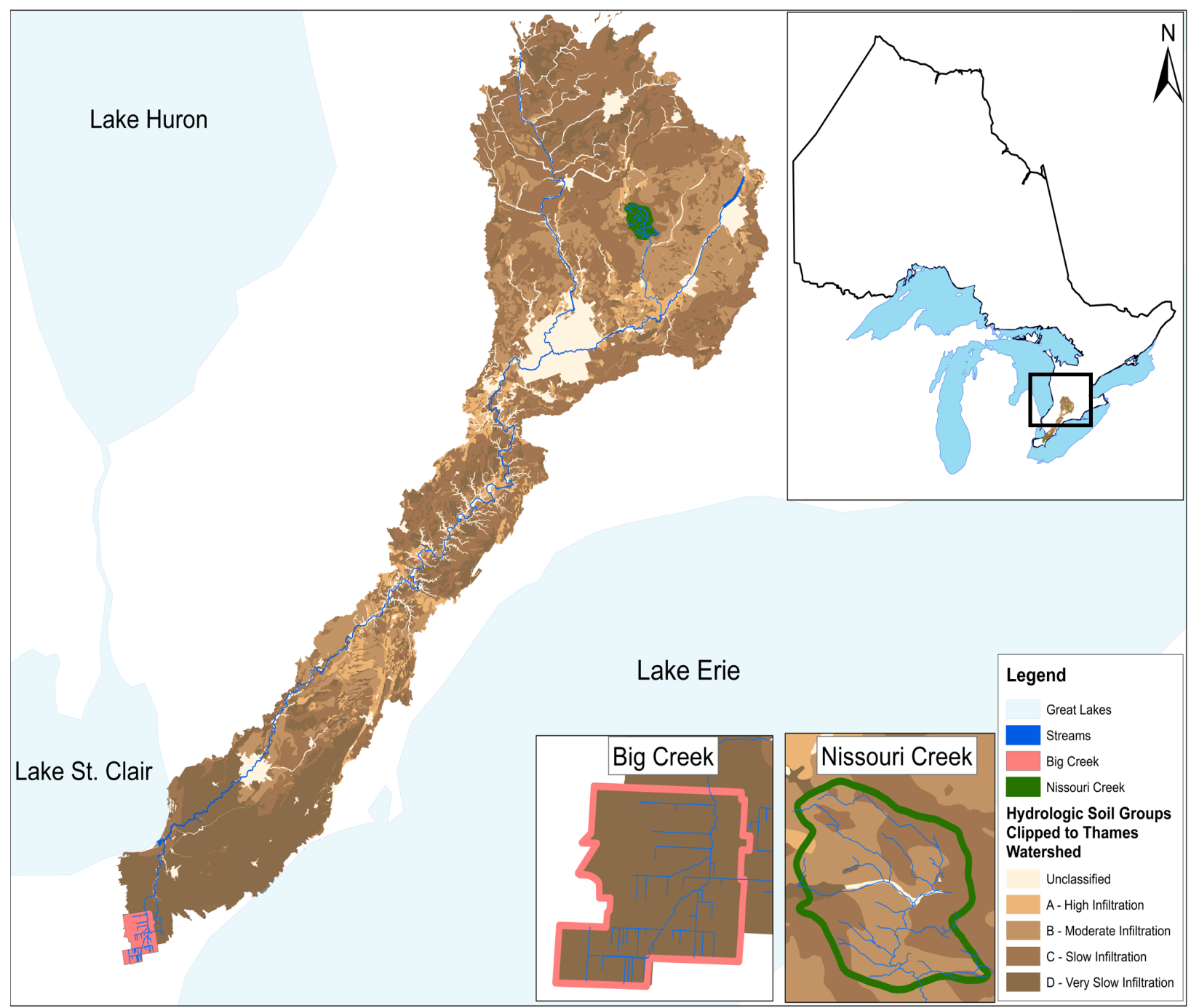

Figure 1. The locations and shape of the Big Creek and Nissouri Creek Watersheds located in the larger Upper Thames and Lower Thames Watersheds in Southern Ontario. Hydrologic Soil Groups are also shown. Streams, Hydrologic Soil Groups, and Great Lakes shapefiles provided by the Ontario Ministry of Natural Resources.

The objective of this study was to:

Conduct a P soil balance for each watershed and compare the watersheds in a "then and now analysis". 


\section{Data and Methods}

\subsection{Study Areas}

\subsubsection{Nissouri Creek}

Nissouri Creek is located east of London, Ontario, Canada in Oxford County (Figure 1 shown previously). Nissouri Creek flows into the upper Thames River which empties into Lake St. Clair that is a part of the Great Lakes system. The watershed is approximately $35 \mathrm{~km}^{2}$ in size. The topography of the watershed is dominated by slopes of less than $5 \%$ and the soil in the area is comprised of a medium textured glacial till silty loam (Frank and Ripley, 1977).

During the 1970's, corn was the principal crop grown in the watershed (44\%), followed by hay and pasture (21\%), small grains (5\%). There were significant cattle operations, and a few swine and poultry operations in the watershed. Nissouri Creek was characterized as high intensity for row crop area, livestock production, manure application, and medium intensity for commercial fertilizer application (Frank and Ripley, 1977). Presently, the predominant crops in Nissouri Creek are a mixture of cash crops (corn, soybeans, and wheat) (AAFC, 2019) and still contains a high intensity of livestock production and manure application. The majority of the farms in Nissouri Creek are beef and dairy farms.

\subsubsection{Big Creek}

Big Creek is located north east of Leamington, Ontario, Canada in Essex County. Big Creek flows into the terminus of the Thames River at Lake St. Clair. The watershed is approximately $50 \mathrm{~km}^{2}$ in size. The topography of the watershed is primarily flat of slopes less than $1 \%$ and the soil in 
the area is comprised of a Brookston clay soil with some sand spot phase overlays in the southern corners (Frank and Ripley, 1977).

During the 1970's, cash crops were the principal crops grown in the watershed, with a few vegetables. Livestock production was a very minimal activity in the watershed. Big Creek was characterized as high intensity for row crop area, medium intensity for commercial fertilizer application, and low intensity for livestock production and manure application (Frank and Ripley, 1977). Presently Big Creek is high intensity of row crops that are predominantly cash crops (AAFC, 2019), with a low intensity of livestock and manure production. The majority of the livestock in Big Creek are beef cattle, hogs, and horses used for pleasure riding.

\subsection{Historical and Present-Day Agricultural Land Use and Management Data}

Current agricultural land use and management data was obtained for the watersheds through farm operator interviews. Every farmer which farmed in the respective watershed boundary were invited to be interviewed. Farmers obtained a small incentive for taking part in the survey, primarily in partial reimbursement in soil sampling fees. The farm operator interviews were conducted between 2017 and 2018 to obtain data for the years of 2015 - 2019. Field specific land use and management data collected included: size of fields, cropping, tillage, manure application, fertilizer application, tile drainage, cover crops, livestock type and numbers, manure storage, soil testing, and knowledge of management programs. AGRI-Model survey sheets are included in Appendix A.

All the historical land use and management data used for this study came from the PLUARG studies with the majority of the data published by Frank and Ripley (1977) and PLUARG (1974). Frank and Ripely (1977) completed a questionnaire survey between 1975 - 
1976 in eleven small $\left(<75 \mathrm{~km}^{2}\right)$ agricultural watersheds. The watersheds were selected to represent the province, with differences in soil type, agricultural activity, and topography. Questions asked (Appendix B) included: crop production, livestock production, land preparation, manure use, fertilizer use, and pesticide/herbicide use. An example of the historical data from the PLUARG studies shows a field-by-field crop map for the Nissouri watershed in 1974 (Figure 2). This map allows us to see which field grew what crops for that specific year within the watershed while also allowing us to digitize it into a GIS file.

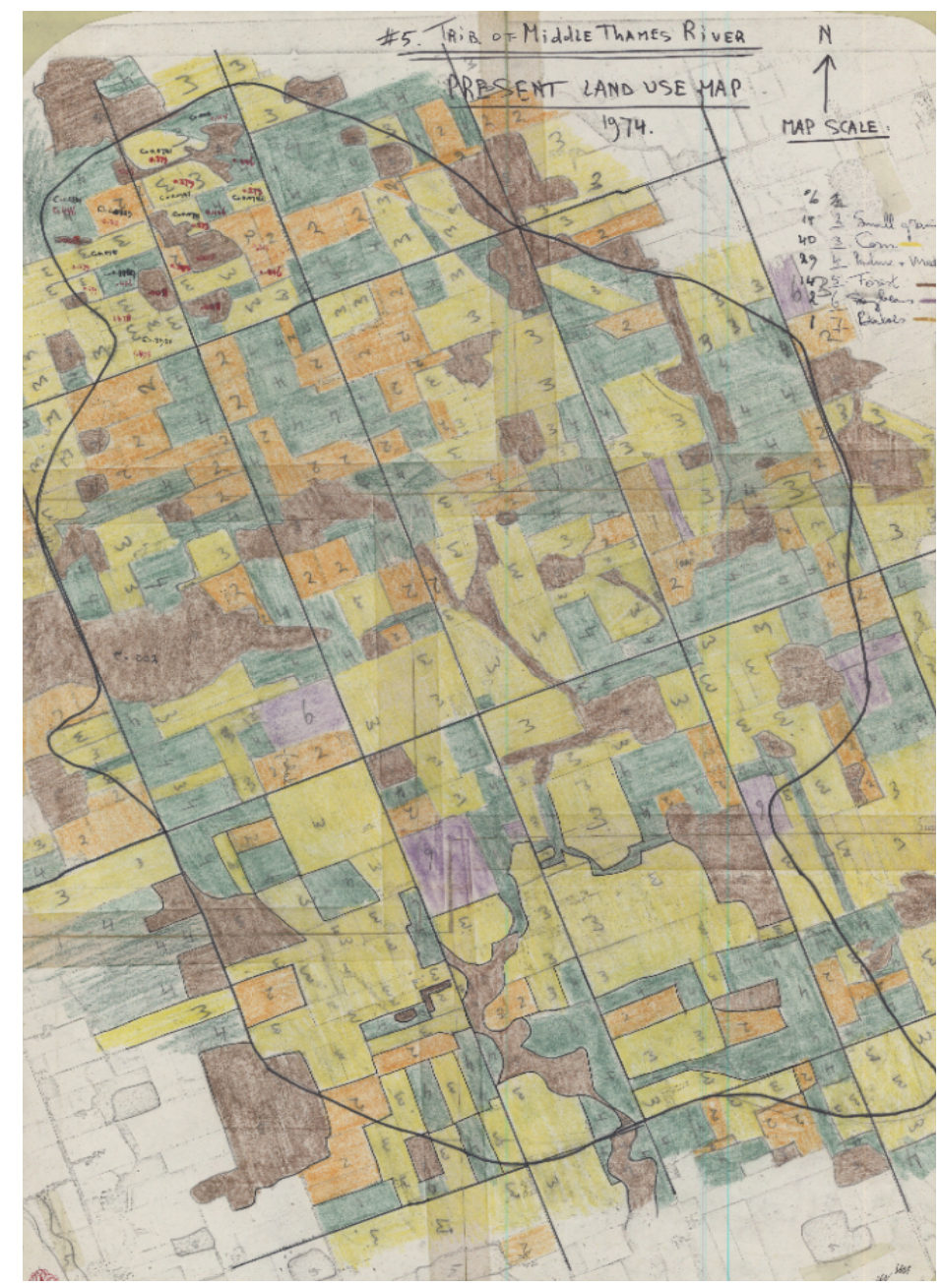

Figure 2. Coloured field by field crop map for the Nissouri watershed in 1974, this map allows us to see which field grew what crops for the specific year within the watershed. Small Grains - Orange, Corn - Yellow, Soybeans - Purple, Pasture and Meadow - Green, Forest and Woodlands - Brown. 


\subsection{Land Use}

The AGRI-Model survey data was used to determine spatially and temporally specific field crop information for the farmers that participated in our study. Shapefiles were created to map out where certain farmers' fields were, and their specific field crops grown between 2015 to 2018. To make sure there is watershed wide data amongst the watersheds Agriculture and Agri-Food Canada (AAFC) publishes field by field crop data based on remotely sensed data for most of the province yearly with coverage including the chosen watersheds for this study (AAFC, Multiple: 2015...2018). This allowed a complete crop type coverage for each watershed, for the fields that did not take part in the AGRI-Model survey. Using satellite data, field boundaries were digitized and transcribed to determine the total acreage of all fields within the watershed for a specific crop type. Once all the fields were digitized into ESRI ArcMap, specific farmer ID's and crop type attributes were added. For fields that did not take part in the AGRI-Model survey, crop type was determined using AAFC Annual Crop Inventory data for the specified time period of 2015 to 2019. Currently AAFC Annual Crop Inventory data meets an overall target accuracy for Ontario crops between $85-91 \%$ at a spatial resolution of 30m (AAFC, 2019). To confirm accuracy of the AAFC Annual Crop Inventory data 25 random accuracy assessments points were added to our known fields for comparison between our known field crop types and the Annual Crop Inventory data. An error matrix was calculated and the overall average users' accuracy of the AAFC Annual Crop Inventory data in the watersheds was calculated at $91 \%$ which matches with AAFC own accuracy calculations. 


\subsection{Fertilizer Application}

Using data from the AGRI-Model survey, fertilizer rates were averaged for specific crop types across the different years. For fields where there was no known fertilizer application data, the digitized AAFC Annual Crop Inventory data was used to determine which crops were in specific fields. Using the AAFC data it was assumed the average rates of $\mathrm{P}$ fertilizer of farmers who took part in the AGRI-Model survey applied to their fields can correspond to similar fields with the same crops.

\subsection{Livestock Counts and Manure Amounts}

\subsubsection{Livestock Counts}

Using data from the AGRI-Model survey total livestock counts were collected and summed for each farmer. AGRI-Model surveyed barns were digitized and mapped in ArcGIS to determine where specified farmers barns and animals were within the watershed. All other barns within the watershed were also digitized and mapped from satellite imagery dated July 2, 2018 and following similar methods to techniques developed by the MECP and Ontario Ministry of Agriculture, Farming and Rural Affairs (OMAFRA) staff specialists (communicated unpublished material). An example of a known poultry barn (Figure 3 ) and a dairy cattle barn (Figure 4).

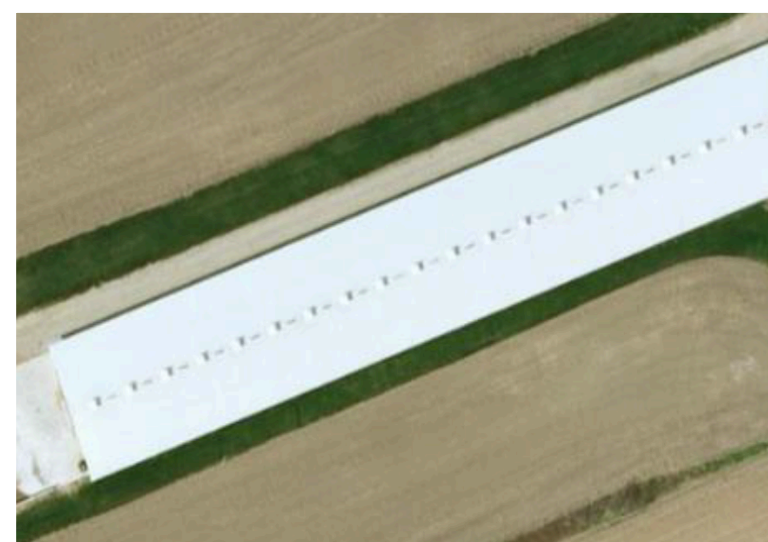

Figure 3. A typical poultry barn in Southern Ontario.

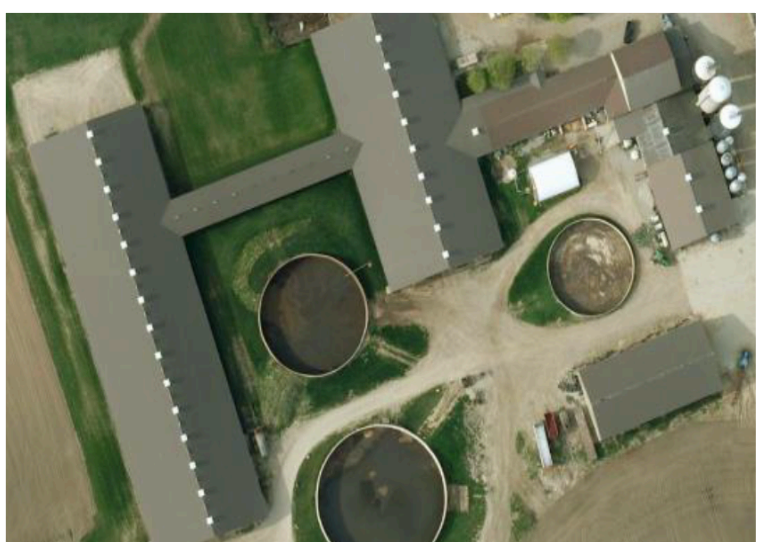

Figure 4. A typical dairy barn in Southern Ontario. 
Known poultry barns are distinguished by typically a long rectangular shape, air vents in the roof, no outdoor manure storage, and propane tanks are located near the barn. Known dairy barns typically have manure lagoons which are circular, air vents in the roof, usually are multiple connected barns, and grain silos are usually nearby. From the digitized barns, barn area was calculated to estimate livestock totals in the unknown barns. Using the AGRI-Model farmer survey data the amount of livestock per barn area for beef cattle, dairy cattle, poultry, sheep, and hogs were calculated. From these rates lower and upper confidence intervals were calculated for each livestock type. The calculated uncertainties were used to determine total livestock counts in unknown barns. Confidence intervals were calculated by determining the standard deviation and standard error of the mean rates.

\subsubsection{Manure Amounts and Phosphorus Content}

The total estimated livestock counts were converted into Animal Units, which represents a thousand pounds of live animal weight, and provides a common method of aggregating different types of livestock. Animal Units were calculated using known animal unit values from (Kellog et. al., 2000), which were also used by Bruulsema et al. (2011). The amount of cycles per year was also taken into account with the animal unit numbers adjusted accordingly. For example, there are 2 cycles of turkeys for slaughter in a typical agricultural year. Animal Units were used to calculate the total amount of manure excreted per year for each animal unit of a specific animal. From this the pounds of $\mathrm{P}$ per ton of manure was calculated for both before and after losses using rates from Kellog et. al. (2000). Before losses would be manure excreted from an animal and collected, where after losses would be not all manure is collected or the manure is degraded by other materials such as bedding which would decrease the $\mathrm{P}$ concentration. The livestock industry has significantly 
increased livestock output over the years, therefore increasing the manure excretion rates. Precise estimates of the rate of change in manure excretion is unavailable but the consensus is that manure excretion rates have increased in the last 50 years (Bruulsema et al., 2011). Following Bruulsema et al. (2011) where they assumed the excretion rates were valid for the year 1990 based on the Kellog et al. (2000) report, and for each year after 1990 increased the excretions rates by $0.5 \%$ per year and likewise decreased rates by $0.5 \%$ per year for each year before 1990 . Using this method, the livestock numbers for the 1970's time period were decreased by $7.5 \%$ to correct the excretion rates. For the present-day livestock numbers in 2015, were adjusted by $12.5 \%$ from the 1990 excretion totals. An assumption in this study is that all manure produced within the watershed does not leave the watershed. Estimating the manure $\mathrm{P}$ inputs was chosen instead of using reported manure application rates from farmers due to the fact that reported rates are not precise taking into account nutrient content, and most manure nutrient contents are not tested or known by farmers when it is applied to their fields.

\subsection{Crop Removal}

Crop P removal was calculated for both watersheds during the 1970's time period as well as for the 2010's time period. This was calculated by taking the total acres of each crop grown and multiplying each by the average yield for each specific crop type from the AGRI-Model survey data to determine the total yield of each crop type as either total bushels or tons of a specific crop type. The total yield of each crop was than multiplied using standard crop P removal values in either pounds of $\mathrm{P}_{2} \mathrm{O}_{5}$ per bushel or pounds of $\mathrm{P}_{2} \mathrm{O}_{5}$ per ton of crop from the OMAFRA publication Agronomy Guide for Field Crops Table 9-15 (OMAFRA, 2017). This gave an estimated low and high amount of P removal per specific crop. 95\% Confidence Intervals were calculated for each 
specific crop as lbs of P removal per acre of Crop, for each watershed. Confidence intervals were calculated by determining the standard deviation and standard error of the mean rates. An example of Big Creek confidence intervals is shown in Table 1.

Table 1. The average $k g$ of $P$ removed per acre of a specific crop and $95 \%$ confidence intervals are shown.

\begin{tabular}{|c|c|c|c|c|c|c|}
\hline Crop & $\mathrm{N}$ & $\begin{array}{c}\text { Average P } \\
\text { Removal (kg } \\
\text { P/acre) }\end{array}$ & $\begin{array}{c}\text { Standard } \\
\text { Deviation }\end{array}$ & $\begin{array}{c}\text { Standard } \\
\text { Error }\end{array}$ & $\begin{array}{c}\text { Confidence } \\
\text { Lower }\end{array}$ & $\begin{array}{c}\text { Confidence } \\
\text { Upper }\end{array}$ \\
\hline Corn & 92 & 31 & 7 & 1 & 29 & 32 \\
\hline Hay & 8 & 25 & 5 & 2 & 22 & 29 \\
\hline Soybeans & 226 & 18 & 4 & 1 & 17 & 18 \\
\hline Wheat & 64 & 19 & 5 & 0.5 & 17 & 20 \\
\hline
\end{tabular}

P Crop Removal was calculated using the confidence intervals and the total crop yields, to give the total amounts of kilograms of P removed by the field crops between the years of 2015 to 2018. To calculate the P removed during the 1974 - 1976 time period there was no historical crop yield data but there was total crop field data from the PLUARG reports, to use the total acreage data a ratio was developed from 1974 - 1976 Census of Agriculture data from Statistics Canada using average crop yield for the South West Ontario Region and using crop yield data for the present day. The calculated ratios were than multiplied by the $2015-2018$ average crop yields in the watershed and the total crop acres during the 1974 - 1976 time period. This calculation provided an estimated total crop yield for the 1974 - 1976 time period. The total crop yield was than multiplied with the average $\mathrm{P}$ removal values from OMAFRA.

\subsection{Stream Losses}

Total P (TP) Loadings were calculated and provided by Sorichietti et al. (in preparation). TP loadings were recalculated for the 1974 - 1976 time period from the historical data, as well TP loadings were calculated for the present day from collected data between May 1 ${ }^{\text {st }}, 2016$ to April 
$30^{\text {th }}, 2018$. Both time periods collected samples during both base-flow and storm-flow conditions.

The TP calculations were derived using the Beale Ratio Estimator based on the assumption that the ratio between load and discharge remains constant for the estimated loading period. The Beale Ratio Estimator is calculated by taking the mean daily flow for the period of interest over the mean daily flow on days when concentration was measured, multiplied by a correction factor (Richards, 1998). Tin (1965) described that the Beale Ratio has been widely used to calculate surface loadings of receiving waters in the Great Lakes systems. The present-day data was stratified based on growing (May - October) and non-growing (November - April) season. To estimate error associated with the Beale Ratio calculations, a bootstrapping method was utilized to compute the $95 \%$ and $90 \%$ confidence intervals. This was accomplished by 2000 bootstrap iterations which involved resampling and recalculating the Beale load estimate. To calculate the yearly loads and confidence intervals, a random value from each 6-month seasonal distribution was used to calculate an overall estimate. This was repeated until a distribution of 2000 values were obtained. The mean value of this distribution is used as the reported load and confidence intervals were obtained as before.

\subsection{Quality Assurance and Quality Check}

Verifying the AGRI-Model survey data is not a simple task to accomplish. The reason being is that there is very minimal data at such small scales as the Nissouri Creek and Big Creek watersheds. Most accessible data are either provided at a county or provincial scale. There is no known fertilizer application data available for comparison. The only comparison that is possible is fertilizer sale data at a county scale. A majority of data sets also contain some degree of error. The AGRI-Model data was compared to various datasets to verify if there was similarity in 
published and the surveyed numbers. Fertilizer P application was compared to another study completed by the IJC in 2018. Animal Count numbers and crop yields were compared with Statistics Canada Census of Agriculture. Where animal counts were based on census day counts for 2016 .

Standard error (Eqn. 1) was calculated on each of the four components of the $\mathrm{P}$ balance to determine the amount of error in each.

$$
S E=\frac{\sigma}{\sqrt{n}}(\text { Eqn. 1) }
$$

With each component's standard error calculated, error propagation (Eqn.2) was computed to determine the overall estimated error for the $\mathrm{P}$ balance. Error propagation allows the calculation of overall uncertainty when multiple uncertainties are combined. When one of the uncertainties is significantly greater than the other, the more certain quantity contributes essentially nothing to the uncertainty of the sum (Taylor, 1996).

$\delta$ Balance $=\sqrt{\delta(\text { Fert } .)^{2}+\delta(\text { Manure })^{2}+\delta(\text { Stream Loss })^{2}+\delta(\text { Crop Removal })^{2}}($ Eqn.2) 


\section{Results}

\subsection{Land Use and Management Practices}

Surveyed coverage in Nissouri Creek occurred with 18 farmers farming 3,493 acres out of 6,255 acres or $56 \%$ of the total agricultural land. Surveyed coverage in Big Creek occurred with 14 farmers farming 6,163 acres out of 11,569 acres or $53 \%$ of the total agricultural land. Additional crop information was obtained from AAFC Annual Crop Inventory data for each of the unknown fields in the two watersheds.

In both watersheds land use (percentage of agricultural land) appeared to remain similar between the 1970's and the 2010's, while landcover (crops grown) has slightly changed with the change in the crop types. In both watersheds there was a decrease in the amount of grains grown and a major increase in the quantity of soybeans grown (Figure 5). In Nissouri Creek it can be seen that hay and corn crops have remained about constant between the 1970's and the mid 2010's. Soybeans in Nissouri Creek were just starting to be grown in the watershed after the 1970's, with the percentage of soybeans grown increasing from $0 \%$ to $16 \%$ between the 1970's and the 2010's taking the majority of grain crops position which decreased from $28 \%$ during the 1970 's to $2 \%$ for the 2010's. Vegetables have increased in Nissouri Creek from 3\% to 11\%. Big Creek is almost entirely composed of cash crops with corn, soybeans, and grains making up approximately $99 \%$ of the crops grown in the present day and 96\% of the crops during the $1974-1976$ time period. 
Nissouri Creek

1976

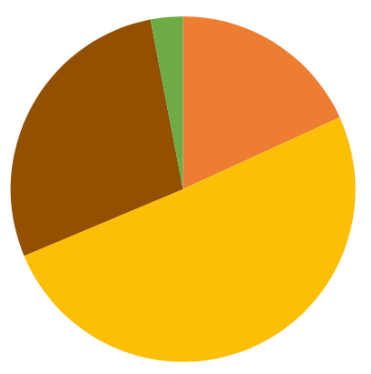

Nissouri Creek

2015-2018

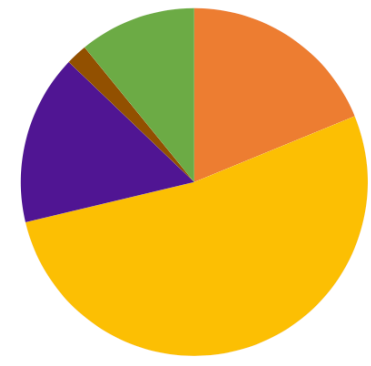

BigCreek 1975

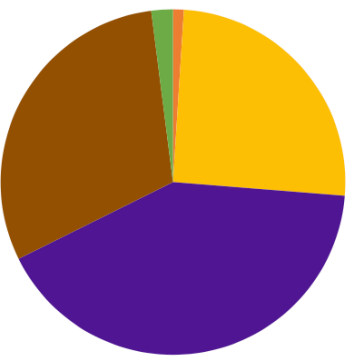

Big Creek

2015-2018

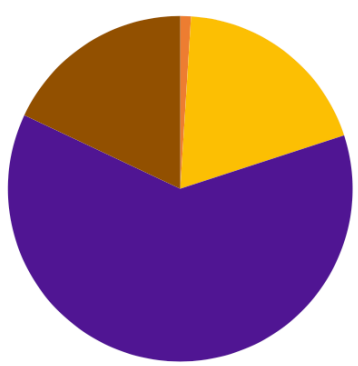

\section{Hay Corn $\square$ Soybeans $\square$ Grains $\square$ Vegetables}

Figure 5. The differences in crop types between the Big Creek and Nissouri Creek Watersheds comparing the years 1975 - 1976 and $2015-2018$.

\subsection{Fertilizer Application}

Fertilizer P nutrients were estimated for both watersheds during the 1974 - 1976 and 2015 - 2018 time periods (Table 2). Fertilizer application amounts are more consistent between crops in Nissouri Creek with a decrease in fertilizer P application to corn (-53\%), wheat (-29\%), and vegetable crops $(-44 \%)$ between the 1975 - 1976 time period and 2015 - 2018 time period. In Nissouri Creek there was an increase in both hay $(+62 \%)$ and grain crops $(+5 \%)$ fertilizer P application. While in Big Creek there was a decrease in fertilizer P application to corn crops ($48 \%)$, while there was a significant increase to soybean fertilizer P application $(+141 \%)$. Wheat crop P application remined about constant (-1\%). 
Table 2. Fertilizer P Application in Big Creek and Nissouri Creek Watersheds. Fertilizer application is shown as kilograms of fertilizer $P$ per hectare of each specific agricultural crop grown. $95 \%$ confidence intervals are shown in brackets for the present day.

\begin{tabular}{|c|c|c|c|c|}
\hline & \multicolumn{2}{|c|}{ Big Creek } & \multicolumn{2}{c|}{ Nissouri Creek } \\
\hline Crop & $\begin{array}{c}1974-1976 \\
\mathrm{kgP} \mathrm{ha}{ }^{-1} \text { of ag } \\
\text { crop }\end{array}$ & $\begin{array}{c}2015-2018 \\
\mathrm{kgP} \mathrm{ha}^{-1} \text { of ag } \\
\text { crop }\end{array}$ & $\begin{array}{c}1974-1976 \\
\mathrm{kgP} \mathrm{ha}^{-1} \text { of ag } \\
\text { crop }\end{array}$ & $\begin{array}{c}2015-2018 \\
\mathrm{kgP} \mathrm{ha}^{-1} \text { of ag } \\
\text { crop }\end{array}$ \\
\hline Corn & 36.31 & $18.81( \pm 2.25)$ & 26.10 & $12.23( \pm 4.19)$ \\
\hline Wheat & 32.34 & $33.55( \pm 4.50)$ & 21.90 & $15.50( \pm 0)$ \\
\hline Hay & - & $37.06( \pm 0)$ & 9.80 & $15.90( \pm 6.92)$ \\
\hline Soybeans & 22.22 & $53.44( \pm 2.80)$ & - & $21.30( \pm 11.68)$ \\
\hline Vegetables & 93.01 & - & 38.50 & $21.50( \pm 15.76)$ \\
\hline Grains & 22.87 & - & 18.20 & $19.20( \pm 0)$ \\
\hline
\end{tabular}

\subsection{Livestock Counts and Manure Amounts}

\subsubsection{Livestock Counts and Animal Units}

Total livestock amounts were estimated for both watersheds during 1974 - 1976 and 2015 - 2018 time periods. Livestock amounts have increased in both watersheds. In Nissouri Creek there was an increase in dairy cattle $(+125 \%)$, veal calves $(+733 \%)$, and swine $(+466 \%)$. There is also now both ovine and turkey livestock in Nissouri Creek. Nissouri livestock declines were visible for both beef cattle (-67\%) and chickens (-93\%). In Big Creek there was an increase in dairy cattle $(+995 \%)$, beef cattle $(+116 \%)$, and veal calves $(+4900 \%)$. In Big Creek there was a decline in swine (-55\%) and chickens are no longer being produced. Animal Units followed a similar trend as total count numbers between the different livestock types in the watersheds. Table $\mathrm{C} 1$ in Appendix $\mathrm{C}$ shows the total count and animal units of each livestock type in each watershed. Figure 6 shows the proportion of animal units across the two watersheds for the two-time periods. 
Big Creek 1974-1975

Animal Units

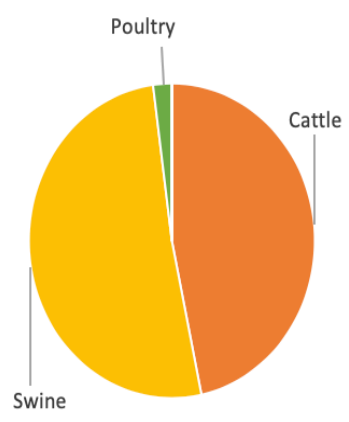

Big Creek 2015-2018

Animal Units

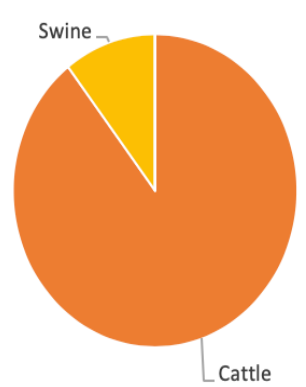

Nissouri Creek 1974-

1975 Animal Units

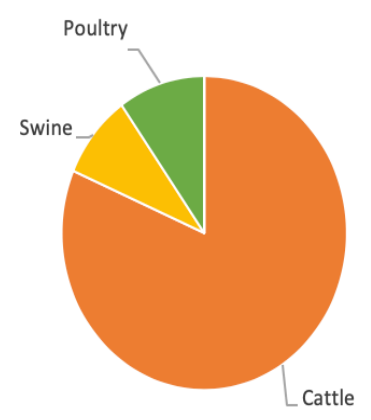

Nissouri Creek 2015-

2018 Animal Units

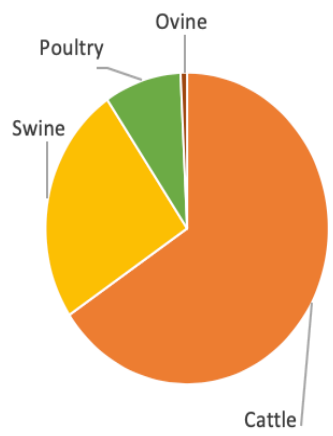

\section{Cattle Swine $\square$ Poultry $\square$ Ovine}

Figure 6. The proportion of animal units in each watershed during the 1974-1975 time period as well as for the 2015-2018 time period.

\subsubsection{Manure Amount and Phosphorus Content}

Excreted manure has increased in both Big Creek and Nissouri Creek relating to the increase in animal units. In Big Creek pounds of $\mathrm{P}$ of manure produced after losses during the 1974 - 1976 time period was 18,383 lbs and 45,843 lbs during the 2015 - 2018 time period that represents an increase of $149 \%$. In Nissouri Creek pounds of $\mathrm{P}$ of manure after losses during the 1974 - 1976 time period was 107,481 lbs and 325,989 lbs during the 2015 - 2018 time period that represents an increase of $203 \%$. Table C2 in Appendix C shows the total amount of manure produced in lbs for both watersheds, as excreted and after losses during the 1974 - 1976 time period as well as for the 2015 - 2018 period. Manure application rates calculated as $\mathrm{kgP} \mathrm{agha}^{-1}$ are shown on the next page (Table 3). 
Table 3. Calculated manure application rates shown as $\mathrm{kgP}$ agha $\mathrm{g}^{-1}$ for both the Nissouri Creek and Big Creek watersheds, $95 \%$ confidence intervals are shown in brackets.

\begin{tabular}{|l|l|l|}
\hline & $\begin{array}{l}1974-1976 \\
k g P \text { agha }\end{array}$ & $\begin{array}{l}2015-2018 \\
\mathrm{kgP}_{\text {agha }}\end{array}$ \\
\hline Nissouri Creek & $8.49( \pm 0.45)$ & $26.25( \pm 3.44)$ \\
\hline Big Creek & $0.84( \pm 0.06)$ & $1.85( \pm 0.75)$ \\
\hline
\end{tabular}

\subsection{Crop Phosphorus Removal}

In Big Creek all crop types with the exception of hay (-3\%) saw an increase in $\mathrm{kg}$ of $\mathrm{P}$ removed per ha of crop. The greatest crop P removal increase was seen in vegetables $(+108 \%)$, followed by grains $(+89 \%)$ corn $(+70 \%)$, and soybeans $(+28 \%)$. In Nissouri Creek there was the new addition of legumes and soybeans between the 2015 - 2018 time periods and the $1974-1976$ time period. Nissouri Creek had a decrease in crop P removal of hay $(-4 \%)$. While there was a substantial increase in corn P removal (+219\%) and grains saw an increase as well $(+116 \%)$. The $\mathrm{kg}$ of $\mathrm{P}$ removed per hectare of a specific agricultural crop of both watersheds, during the 1974 1976 time period as well as for the 2015 - 2018 time period is shown in Table 4.

Table 4. The kg of P removed per crop hectare in both Big Creek and Nissouri Creek during the 1974-1976 time period and for the 2015-2018 time period. 95\% confidence intervals are shown in brackets for the present day. *Legumes and soybeans were not grown in Nissouri Creek during the 1974-1976 time period.

\begin{tabular}{|c|c|c|c|c|}
\hline & \multicolumn{2}{|c|}{ Big Creek } & \multicolumn{2}{c|}{ Nissouri Creek } \\
\hline Crop & $\begin{array}{c}1974-1976 \mathrm{~kg} \\
\text { of P removed } \\
\text { per ha of crop }\end{array}$ & $\begin{array}{c}2015-2018 \mathrm{~kg} \text { of P } \\
\text { removed per ha of } \\
\text { crop }\end{array}$ & $\begin{array}{c}1974-1976 \mathrm{~kg} \\
\text { of P removed } \\
\text { per ha of crop }\end{array}$ & $\begin{array}{c}2015-2018 \mathrm{~kg} \text { of P } \\
\text { removed per ha of } \\
\text { crop }\end{array}$ \\
\hline Corn & 19.57 & $33.26( \pm 0.61)$ & 21.45 & $68.47( \pm 4.85)$ \\
\hline Hay & 28.61 & $27.64( \pm 2.14)$ & 30.93 & $29.84( \pm 1.50)$ \\
\hline Grains & 10.49 & $19.81( \pm 0.58)$ & 12.22 & $26.40( \pm 1.02)$ \\
\hline Soybeans & 14.74 & $18.83( \pm 0.17)$ & - & $21.00( \pm 0.45)$ \\
\hline Vegetables & 7.92 & $16.50( \pm 0)$ & - & - \\
\hline Legumes & - & - & - & $1.75( \pm 0)$ \\
\hline
\end{tabular}




\subsection{Stream Losses}

The provided P loadings from the MECP for Big Creek show a TP loading of $1.46 \mathrm{kgP}$ agha $^{-1} \mathrm{yr}^{-1}$ that represents $7 \%$ of total $\mathrm{P}$ additions to the watershed during the $1974-1976$ time period. For the 2015 - 2018 time period the TP loadings in Big Creek is $2.70 \mathrm{kgP} \mathrm{agha}^{-1} \mathrm{yr}^{-1}$ that represents $9.8 \%$ of $\mathrm{P}$ additions. In Nissouri Creek during the 1974 - 1976 time period TP loadings were $0.99 \mathrm{kgP}_{\text {agha }}{ }^{-1} \mathrm{yr}^{-1}$ that represents $2.7 \%$ of total $\mathrm{P}$ additions in the watershed and for the 2015 - 2018 time period TP loadings in Nissouri Creek is $1.72 \mathrm{kgP}$ agha ${ }^{-1} \mathrm{yr}^{-1}$ or $3.6 \%$ of total P additions. Nissouri Creek observed an increase of 74\% in TP loadings between 1974 - 1976 time period and the 2015 - 2018 time periods, while Big Creek seen an increase of $85 \%$ in TP loadings per hectare per year (Table 5).

Table 5. The TP loadings for both Nissouri Creek and Big Creek watersheds, between the 1970's and the 2010 's. 95\% confidence intervals are shown in brackets.

\begin{tabular}{|l|l|l|}
\hline & $\begin{array}{l}1974-1976 \\
\mathrm{kgP} \mathrm{agha}^{-1} \mathrm{yr}^{-1}\end{array}$ & $\begin{array}{l}2015-2018 \\
\mathrm{kgP} \mathrm{agha}^{-1} \mathrm{yr}^{-1}\end{array}$ \\
\hline Nissouri Creek & $0.99( \pm 0.15)$ & $1.72( \pm 0.18)$ \\
\hline Big Creek & $1.46( \pm 0.27)$ & $2.70( \pm 0.15)$ \\
\hline
\end{tabular}

\subsection{Overall P Balance}

\subsubsection{Overall P Balance for Nissouri Creek Watershed}

During the 1970 's time period manure additions were calculated at $8.49 \mathrm{kgP} \mathrm{ha}^{-1}$ and fertilizer additions calculated at $27.89 \mathrm{kgP} \mathrm{ha}^{-1}$, for an overall addition total of $36.38 \mathrm{kgP} \mathrm{ha}^{-1}$. Crop removal was calculated at $20.55 \mathrm{kgP} \mathrm{ha}^{-1}$ and stream losses at $0.99 \mathrm{kgP} \mathrm{ha}^{-1}$, for an overall removal total of $21.54 \mathrm{kgP} \mathrm{ha}^{-1}$. Calculating the overall P balance for Nissouri Creek during the $1974-1976$ time period showed $14.84 \mathrm{kgP} \mathrm{ha}^{-1}$ stored within the watershed per the time period.

During the present-day manure additions were calculated at $26.25 \mathrm{kgP} \mathrm{ha}^{-1}(+209 \%)$ and fertilizer additions were calculated at $21.53 \mathrm{kgP} \mathrm{ha}^{-1}(-22 \%)$, for an overall addition total of 47.78 
$\mathrm{kgP} \mathrm{ha}^{-1}(+31 \%)$. Crop removal was calculated at $48.25 \mathrm{kgP} \mathrm{ha}^{-1}(+135 \%)$ and stream losses at $1.72 \mathrm{kgP} \mathrm{ha}^{-1}(+74 \%)$, for an overall removal total of $49.97 \mathrm{kgP} \mathrm{ha}^{-1}(+132 \%)$. Calculating the overall balance for Nissouri Creek during the 2015 - 2018 time period showed $-2.19 \mathrm{kgP} \mathrm{ha}^{-1}$ ($115 \%$ ) is depleted within the watershed for this time period. Figure 7 below shows the overall P balance as well as each category used for the overall calculation for the Nissouri Creek watershed for the time periods of $1974-1976$ and $2015-2018$.

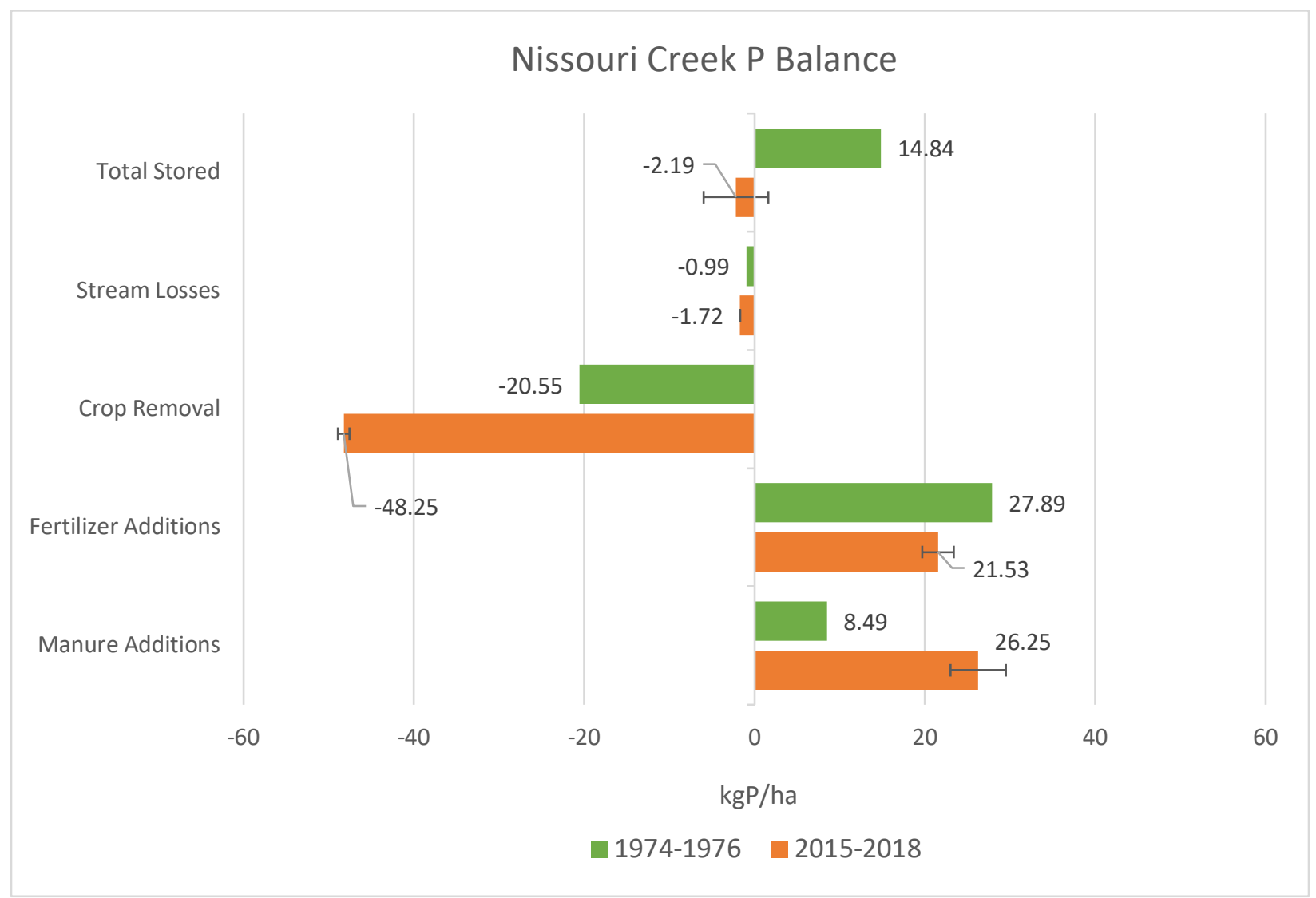

Figure 7. Nissouri Creek overall P balance, with each P addition and removal shown for the 1974-1976 and 2015- 2018 time periods. Standard Error Bars are shown for the 2015-2018 data.

\subsubsection{Overall P Balance for the Big Creek Watershed}

During the 1974 - 1976 time period manure additions were calculated at $0.84 \mathrm{kgP} \mathrm{ha}^{-1}$ and fertilizer additions were calculated at $19.93 \mathrm{kgP} \mathrm{ha}^{-1}$, for an overall addition total of $20.77 \mathrm{kgP}$ $\mathrm{ha}^{-1}$. Crop removal was calculated at $14.00 \mathrm{kgP} \mathrm{ha}^{-1}$ and stream losses at $1.48 \mathrm{kgP} \mathrm{ha}^{-1}$, for an 
overall removal total of $15.48 \mathrm{kgP} \mathrm{ha}^{-1}$. Calculating the overall $\mathrm{P}$ balance for Big Creek during the 1974 - 1976 time period showed $5.29 \mathrm{kgP} \mathrm{ha}^{-1}$ stored within the watershed during this time period.

During the 2015 - 2018 time period manure additions were calculated at $1.85 \mathrm{kgP} \mathrm{ha}^{-1}$ $(+120 \%)$ and fertilizer additions were calculated at $25.85 \mathrm{kgP} \mathrm{ha}^{-1}(+30 \%)$, for an overall addition total of $27.70 \mathrm{kgP} \mathrm{ha}^{-1}(+33 \%)$. Crop removal was calculated at $20.19 \mathrm{kgP} \mathrm{ha}^{-1}(+44 \%)$ and stream losses at $2.74 \mathrm{kgP} \mathrm{ha}^{-1}(+85 \%)$, for an overall removal total of $22.93 \mathrm{kgP} \mathrm{ha}^{-1}(+48 \%)$. Calculating the overall $\mathrm{P}$ balance for Big Creek during the present-day showed $4.77 \mathrm{kgP} \mathrm{ha} \mathrm{h}^{-1}(-10 \%)$ stored within the watershed for this time period. Figure 8 below, shows the overall $\mathrm{P}$ balance as well as each category used for the overall calculation for the Big Creek watershed for the time periods of $1974-1976$ and $2015-2018$.

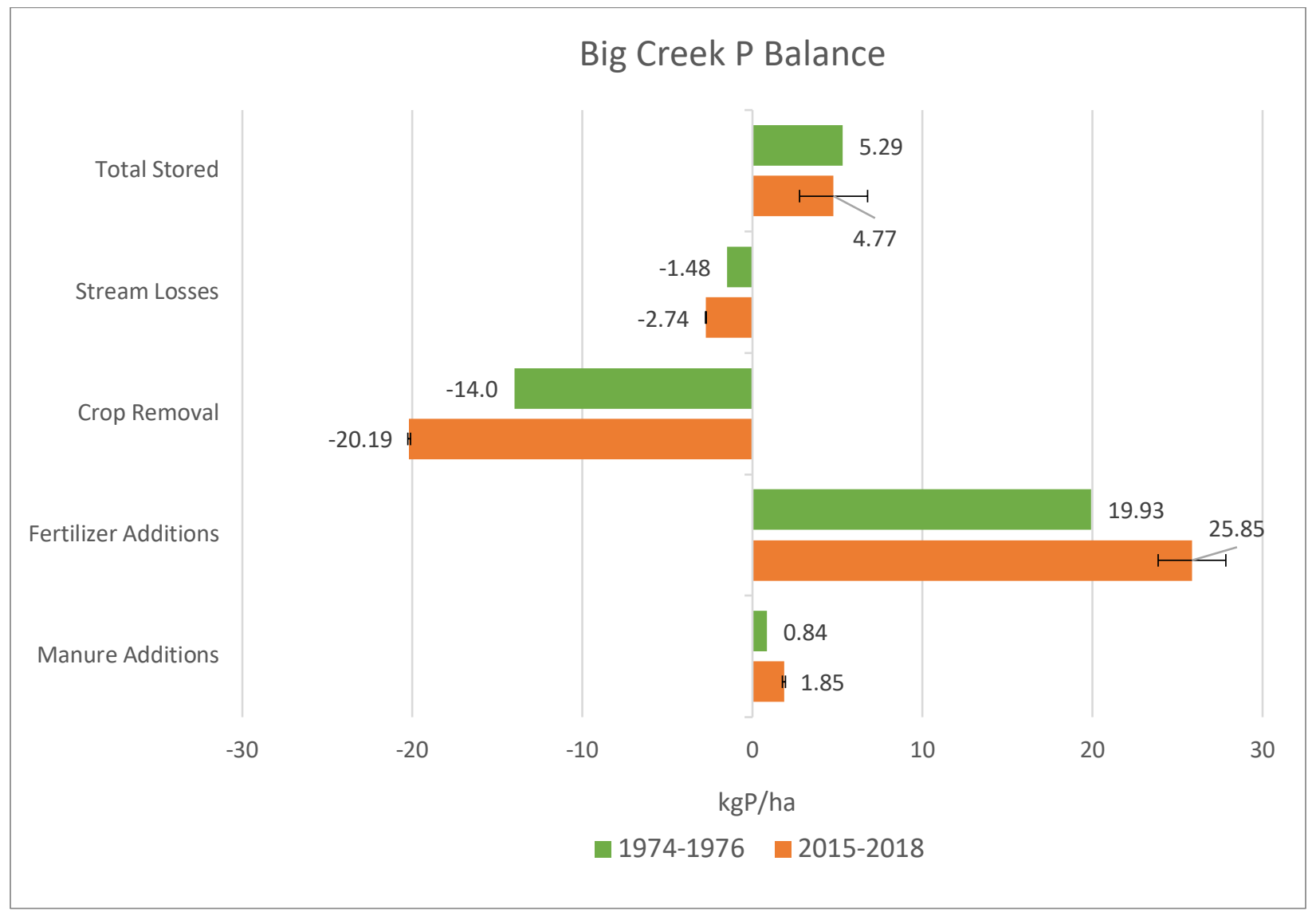

Figure 8. Big Creek overall $P$ balance, with each $P$ addition and removal shown for the 1974-1976 and 2015-2018 time periods. Standard Error Bars are shown for the 2015 - 2018 data. 


\subsection{Quality Assurance and Quality Check}

IJC (2018) found fertilizer P application was $>25 \mathrm{~kg} \mathrm{P} \mathrm{ha}^{-1}$ in 1987 and decreased to $15 \mathrm{~kg}$ $\mathrm{P} \mathrm{ha}^{-1}$ in 2007 for the Canadian portion of the WLEB. The overall decreases in fertilizer application is in agreement with the AGRI-Model survey data.

Animal count numbers based on Census of Agriculture data from 2016 showed the total cattle reported at 25,981 in the Zorra Ontario census consolidated subdivision and 849 total cattle for the Lakeshore Ontario census consolidated subdivision (Statistics Canada, Table 32-10-042401). In 2016 the total swine was reported at 178,670 in Zorra Ontario census consolidated subdivision and unreported due to confidentially reasons in the Lakeshore Ontario census subdivision (Statistics Canada, Table 32-10-0426-01). A weighted area calculation of the Census of Agriculture data showed 1,434 cattle in Nissouri Creek, and 54 cattle in Big Creek. While for Nissouri Creek weighted area calculation showed 9,865 swine. The AGRI-Model survey found 4,482 cattle and 14,838 swine in Nissouri Creek. In Big Creek it was found there was 1,194 cattle and 1,037 swine. The cattle numbers do not agree with this study's calculations while the swine numbers are similar for Nissouri Creek but there still seems to be an overestimation. A point to make again is the Census of Agriculture only counts livestock that are on the farm during census day.

Census of Agriculture data for crop yields for the Southern Ontario Small Area region that encompasses both watersheds. In 2017 census yield data was calculated for corn at 179 bushels acre $^{-1}$, soybeans 49 bushels acre ${ }^{-1}$ and wheat 88 bushels acre ${ }^{-1}$. In Big Creek this study calculated crop yields at 189 bushels acre $^{-1}$ for corn, 52 bushels acre ${ }^{-1}$ for soybeans, and 81 bushels acre ${ }^{-1}$ for wheat. In Nissouri this study calculated yields at 181 bushels acre ${ }^{-1}$ for corn, 54 bushels acre ${ }^{-1}$ for 
soybeans, and 102 bushels acre ${ }^{-1}$ for wheat. The Agri-Model crop yields were found to be aligned with the Census of Agriculture data.

Error propagation was completed on all calculated data (Eqn. 2), propagating to the final $\mathrm{P}$ balance. Error propagation results are shown in Table 6, for each watershed and each input to the final error propagation equation.

Table 6. Mean total value and error propagation results are shown for both Big Creek and Nissouri Creek for the 2015 - 2018 time period.

\begin{tabular}{|c|c|c|c|c|}
\hline Variable & $\begin{array}{c}\text { Big Creek } \\
\text { Calculated } \\
\text { Value }\left(\mathrm{kgP} \mathrm{ha}^{-1}\right)\end{array}$ & $\begin{array}{c}\text { Big Creek } \\
\text { Calculated } \\
\text { Error }\end{array}$ & $\begin{array}{c}\text { Nissouri Creek } \\
\text { Calculated Value } \\
\left(\mathrm{kgP} \mathrm{ha}^{-1}\right)\end{array}$ & $\begin{array}{c}\text { Nissouri Creek } \\
\text { Calculated Error }\end{array}$ \\
\hline $\begin{array}{c}\text { Fertilizer P } \\
\text { Application }\end{array}$ & 25.85 & 1.99 & 21.53 & 1.85 \\
\hline Manure P Application & 1.85 & 0.09 & 26.25 & 3.25 \\
\hline Stream P Losses & -2.70 & 0.02 & -1.72 & 0.03 \\
\hline Crop P Removal & -20.19 & 0.08 & -48.25 & 0.68 \\
\hline Total Balance & $\mathbf{4 . 7 7}$ & $\mathbf{2 . 0 0}$ & $\mathbf{- 2 . 1 9}$ & $\mathbf{3 . 8 0}$ \\
\hline
\end{tabular}




\section{Discussion}

This study conducted a comprehensive "then and now" assessment of land use and management activities as well as looked at a $\mathrm{P}$ farm balance for two watersheds and compared the watersheds in a "then and now analysis" between the 1970's and the 2010's. This study looked at and calculated $\mathrm{P}$ fertilizer application rates, $\mathrm{P}$ manure application rates, the quantity of $\mathrm{P}$ removed with crop harvest, and the stream losses of $\mathrm{P}$ within two watersheds over two different time periods separated by $\sim 40$ years. An important point to make is that this study looked at two different time frames the 1970's and the 2010's where it is unknown of what has happened in the watersheds between these two periods. During this unknown time period soils may have amassed a storage of $\mathrm{P}$ and may presently be seeping $\mathrm{P}$ back into the watershed.

This study shows that there have been phosphorus balance changes in Southern Ontario watersheds. Results suggest that while the balance has shifted, the direction of that shift may not be the same in each catchment. In Nissouri Creek during the $1974-1976$ time period there was an accumulation in the $\mathrm{P}$ balance within the watershed of approximately $14.84 \mathrm{~kg}$ of $\mathrm{P}$ per hectare of agricultural land within the watershed, around the years of 2015 - 2018 there was a depletion of $\mathrm{P}$ within the watershed of $-2.19 \mathrm{~kg}$ of $\mathrm{P}$ per hectare of agricultural land. While in Big Creek, during the 1974 - 1976 time period the accumulation of $\mathrm{P}$ within the watershed was $5.29 \mathrm{~kg}$ of $\mathrm{P}$ per hectare of agricultural land within the watershed, around the years of $2015-2018$ there is still an accumulation of $\mathrm{P}$ within the watershed of approximately $4.77 \mathrm{~kg}$ of $\mathrm{P}$ per hectare of agricultural land. In both watersheds the amount of agricultural land appeared to remain the same between the 1970 's and the 2010's, while the type of crops grown has slightly changed with a greater emphasis on cash crops. In both watersheds there was a decrease in the amount of grains grown and a major increase in the quantity of soybeans being grown. 


\subsection{P Balance Agreement to Other Studies}

It was expected to see a decline of $\mathrm{P}$ accumulation within both the watersheds, based on other studies with Nissouri Creek declining by $17.03 \mathrm{kgP} \mathrm{ha}^{-1}$ from the $1974-1976$ time period to the 2015 - 2018 time period and Big Creek declining by $0.52 \mathrm{kgP} \mathrm{ha}^{-1}$ between the $1974-1976$ and the 2015 - 2018 time period. Baker \& Richards (2002) calculated a phosphorus balance for Northwestern Ohio watersheds and calculated a decrease in the net accumulation of $\mathrm{P}$ for both the Maumee and Sandusky watersheds for a similar temporal scale. In 1976 the Maumee net accumulation was approximately $14 \mathrm{kgP} \mathrm{ha}^{-1}$ and decreased to $5 \mathrm{kgP} \mathrm{ha}^{-1}$ in 1995 . The Sandusky watershed net accumulation in 1975 was approximately $9 \mathrm{kgP} \mathrm{ha}^{-1}$ and decreased to $5 \mathrm{kgP} \mathrm{ha}^{-1}$ in 1995.

Powers et al. (2016) found that the Maumee watershed between the years of 1995 and 2010 has been oscillating between $\mathrm{P}$ accumulation and depletion in the watershed which is typically dependent on the P additions. Bast et al. (2009) found that P inputs vastly surpassed removals prior to the 1990's than from 1997 to 2008 in the Lake Erie Basin. They found P crop removal surpassed P inputs for nine out of the eleven years based on manure as applied. Looking at manure as excreted, P crop removal only surpass P inputs in 2007 and 2008. van Bochove et al. (2011) determined that the net $\mathrm{P}$ accumulation for the Northern Lake Erie watershed to be approximately $5 \mathrm{kgP} \mathrm{ha}^{-1}$ in 1981 and approximately $1 \mathrm{kgP} \mathrm{ha}^{-1}$ in 2006. Bruulsema et al. (2011) calculated that P inputs greatly exceeded crop removal until the 1900's in Ontario. They found that crop removal slightly surpassed inputs for some years between 1994 and 2006, with 2006 to 2008 where there was a considerably larger crop removal than of $\mathrm{P}$ inputs. The results from this study are generally similar to larger scale P mass balance studies. This study looking at such a small scale, showed that there may be high variability in P balances spatially across different watersheds in Ontario. 
As well this study suggests there could be some variability in $\mathrm{P}$ balances across different cropping systems. Table 7 shows a comparison of Big Creek and Nissouri Creek with the previously mentioned studies.

Table 7. Comparing other P balance studies with the Big Creek and Nissouri Creek Watersheds. Organized by authors, spatial scale, time periods, balance and units for both the beginning and ending time periods of the respective studies, and the net change in the balance.

\begin{tabular}{|c|c|c|c|c|c|c|}
\hline Authors & Spatial Scale & $\begin{array}{l}\text { Beginning } \\
\text { Time Period }\end{array}$ & $\begin{array}{c}\text { End } \\
\text { Time } \\
\text { Period }\end{array}$ & $\begin{array}{l}\text { Beginning } \\
\text { Balance }\end{array}$ & $\begin{array}{c}\text { End } \\
\text { Balance }\end{array}$ & $\begin{array}{c}\text { Change in } \\
\text { Balance }\end{array}$ \\
\hline $\begin{array}{l}\text { (Baker \& } \\
\text { Richards, } \\
\text { 2002) }\end{array}$ & $\begin{array}{c}\text { Maumee } \\
\text { Watershed in } \\
\text { Ohio }\end{array}$ & 1976 & 1995 & $\begin{array}{c}14 \\
\mathrm{kgP}^{-1} \mathrm{ha}^{-1}\end{array}$ & $\begin{array}{c}5 \\
\mathrm{kgP}^{-1} \mathrm{ha}^{-1}\end{array}$ & $\begin{array}{c}-9 \\
\mathrm{kgP} \mathrm{ha}^{-1}\end{array}$ \\
\hline $\begin{array}{l}\text { (Baker \& } \\
\text { Richards, } \\
\text { 2002) }\end{array}$ & $\begin{array}{c}\text { Sandusky } \\
\text { Watershed in } \\
\text { Ohio } \\
\end{array}$ & 1975 & 1995 & $\begin{array}{c}9 \\
\mathrm{kgP} \mathrm{ha}^{-1}\end{array}$ & $\begin{array}{c}5 \\
\mathrm{kgP} \mathrm{ha}^{-1}\end{array}$ & $\begin{array}{c}-4 \\
\mathrm{kgP} \mathrm{ha}^{-1}\end{array}$ \\
\hline $\begin{array}{c}\text { (Powers et } \\
\text { al., 2016) }\end{array}$ & $\begin{array}{c}\text { Maumee } \\
\text { Watershed in } \\
\text { Ohio } \\
\end{array}$ & 1995 & 2010 & $\begin{array}{c}20 \\
\mathrm{ktP}_{\mathrm{yr}}^{-1}\end{array}$ & $\begin{array}{c}2 \\
\mathrm{ktP} \mathrm{yr}^{-1}\end{array}$ & $\begin{array}{c}-18 \\
\mathrm{ktP}^{\mathrm{yr}}\end{array}$ \\
\hline \multirow[t]{3}{*}{$\begin{array}{c}\text { (Van } \\
\text { Bochove et } \\
\text { al., 2011) }\end{array}$} & $\begin{array}{c}\text { Ontario, } \\
\text { Michigan, and } \\
\text { Ohio } \\
\end{array}$ & 1981 & 2006 & $\begin{array}{c}5 \\
\mathrm{kgP} \mathrm{ha}^{-1}\end{array}$ & $\begin{array}{c}1 \\
\mathrm{kgP} \mathrm{ha}^{-1}\end{array}$ & $\begin{array}{c}-4 \\
\mathrm{kgP}^{-4} \mathrm{ha}^{-1}\end{array}$ \\
\hline & $\begin{array}{c}\text { Nissouri } \\
\text { Creek }\end{array}$ & 1974-1976 & $\begin{array}{c}2015- \\
2018 \\
\end{array}$ & $\begin{array}{c}15 \\
\mathrm{kgP} \mathrm{ha}^{-1} \\
\end{array}$ & $\begin{array}{c}-2 \\
\mathrm{kgP} \mathrm{ha}^{-1}\end{array}$ & $\begin{array}{c}-17 \\
\mathrm{kgP} \mathrm{ha}^{-1}\end{array}$ \\
\hline & Big Creek & 1974-1976 & $\begin{array}{c}2015- \\
2018 \\
\end{array}$ & $\begin{array}{c}5.29 \\
\mathrm{kgP} \mathrm{ha}^{-1}\end{array}$ & $\begin{array}{c}4.8 \\
\mathrm{kgP} \mathrm{ha}^{-1}\end{array}$ & $\begin{array}{c}-0.5 \\
\mathrm{kgP} \mathrm{ha}^{-1}\end{array}$ \\
\hline
\end{tabular}

The Nissouri Creek watershed does agree with what is happening in these previous studies where fertilizer use has decreased and crop P removal has increased, leading to a net loss of P. Big Creek from the calculations is a bit different than Nissouri Creek and other studies. Big Creek saw an average increase in fertilizer use between the 1970's and the 2010's, comparing the 1976 and 2015 - 2018 data averaged across the three years. Fertilizer application increased approximately $30 \%$ between the $1974-1976$ and 2015 - 2018 time periods. Big Creek does not follow the pattern of a net loss of $\mathrm{P}$ like Nissouri Creek or other $\mathrm{P}$ balance studies, there is still an average net accumulation of $4.77 \mathrm{~kg} \mathrm{P}^{-1}$ stored in Big Creek. 


\subsection{P Balance Components}

A decrease in fertilizer P application is expected within watersheds, located in the WLEB of Ontario. Limnotech (2017) using commercial fertilizer P sales determined that in 1986 fertilizer $\mathrm{P}$ application in Southern Ontario averaged to be 20.1-30.0 $\mathrm{kgP} \mathrm{ha}^{-1}$ and for 2006 averaged around $16 \mathrm{kgP} \mathrm{ha}^{-1}$. Bruulsema (2016) also found the phosphorus application trends in the Lake Erie region have decreased. Bruulseam determined that in 1987 fertilizer $\mathrm{P}$ applications were about 45 $\mathrm{kgP} \mathrm{ha}{ }^{-1}$ and decreased up to 2010 to approximately less than $34 \mathrm{kgP} \mathrm{ha}^{-1}$ with an increasing trend from 2010-2012, where in 2012 fertilizer application rates were again above $45 \mathrm{kgP} \mathrm{ha}^{-1}$. IJC (2018) published a report that found in the Canadian portion of the WLEB fertilizer P rates averaged around $16 \mathrm{kgP} \mathrm{ha}^{-1}$ with a maximum of $26 \mathrm{kgP} \mathrm{ha}^{-1}$ in Essex County. Big Creek is located in the Essex County region and this study agrees with the IJC report which found the highest rate of fertilizer P application of $26 \mathrm{kgP} \mathrm{ha}^{-1}$ in 2006 for Essex County, where in Big Creek specifically P fertilizer application was $25.85 \mathrm{kgP} \mathrm{ha}^{-1}$ between 2015 and 2018. The increase in fertilizer application in Big Creek could be due to a variety of factors such as environmental, sociological, and economical factors (Parthasarathy, 1994).

An increase in animal units was expected within these specific watersheds which in turn meant an increase in the amount of manure in both watersheds. This increase in animal units is due to the assumption that livestock are brought to market weight more rapidly than in previous decades (Bruulsema et al., 2016). Nissouri Creek has always been a predominately large livestock production area particularly for cattle with Hofmann (2008) describing the Upper Thames watershed where Nissouri Creek is located, as the second most prominent manure producing watershed in Canada. Bast et al. (2009) determined that the total amount of manure as excreted had increased, they found that the total amount of manure available to be used in the fields has 
remained relatively the same only increasing by $6 \%$ over the past 50 years. Bast et al. (2009) determined Ontario cattle numbers have declined since the 1970's time period and swine numbers have increased, while poultry numbers have increased steadily over the last 50 years. Bruulsema et al. (2016) determined that manure inputs to Ontario watersheds have remained relatively constant between the 1974 - 1976 and 2015 - 2018 time periods. This trend was also supported by LimnoTech (2017) and Han et al. (2012). IJC (2018) found that the amount of manure P application in the Upper Thames Watershed ranged from 7.82 - $25.91 \mathrm{kgP} \mathrm{ha}^{-1}$ between $1986-$ 2012. This is in agreement for the Nissouri Creek watershed, which is in the Upper Thames, where this study calculated $8.49 \mathrm{kgP} \mathrm{ha}^{-1}$ in $1974-1976$ and $26.25 \mathrm{kgP}^{-1}$ between $2015-2018$.

Crop P Removal did see an increase in both watersheds which was expected with an increase in crop yields between the 1970's and the 2010's (Bast et al., 2009; Bruulsema, 2011). According to Statistics Canada (n.d.) the average yield in Southern Ontario for, grain corn increased from $89.5 \mathrm{bu} \mathrm{ac}^{-1}$ in 1976 to $173.7 \mathrm{bu} \mathrm{ac}^{-1}$ in 2018 , soybeans increased from $36.1 \mathrm{bu} \mathrm{ac}^{-1}$ in 1991 to $52.4 \mathrm{bu} \mathrm{ac}^{-1}$ in 2018 , and wheat increased from $49.2 \mathrm{bu} \mathrm{ac}^{-1}$ in 1976 to $84.1 \mathrm{bu} \mathrm{ac}^{-1}$ in 2018. Bast et al. (2009) and Bruulsema et al. (2016) found that crop P removal has increased by $61 \%$ between the $1974-1976$ time period $\left(127 \mathrm{ktP}\right.$ year $\left.{ }^{-1}\right)$ and the $2015-2018$ time period (204 ktP year-1). Overall both studies, determined that crop P removal had approximately doubled between 1955 and 2008.

Stream losses of $\mathrm{P}$ in both watersheds were found to have increased between the 2015 2018 and the 1974 - 1976 time periods. Joosse \& Baker (2011) found that in Lake Erie tributaries overall TP has decreased from over 15,000 metric tons of TP in the early 1970's to around 10,000 metric tons of TP in the 2010's, much of this decrease was the result of reduction in point sources. Their study was at a much different spatial scale than this one and also included the Maumee River 
located in Ohio which is the largest TP contributor to the WLEB. PLUARG (1978) and Richards et al. (2008) found that non-point source P inputs from agricultural land tend to be delivered more intermittently under high flow conditions in which particulate P dominants. Shown by Joosse \& Baker (2011) DRP has increased significantly between the 1990's and the present-day in the Maumee River Basin located in Ohio, which drains into the WLEB, as is Big Creek and Nissouri Creek watersheds. King et al. (2017) found that DRP concentrations at the watershed scale in Ohio for the Lake Erie basin remined constant during one of the wettest periods on record providing a strong linkage showing that legacy $\mathrm{P}$ contributes to current nutrient loadings to Lake Erie. It is beyond the scope of this study to infer the causes of the changes in TP loadings from the watersheds between the 1970's and the present-day. Another study by the MECP is looking into what these causes might be.

\subsection{Implications for P Management}

This study shows that the $\mathrm{P}$ in Lake Erie and possibly elsewhere cannot be solved by a single solution and can involve different confounding factors of different scales and geographies. Presently the overapplication of $\mathrm{P}$ fertilizer does not seem to be causing the re-eutrophication of Lake Erie and other lakes. Attempting to completely balance P will not likely be helpful in solving the eutrophication problems. Presently the $\mathrm{P}$ balance is closer to zero, but losses are higher now in the 2010's than they were in the 1970's. There is little data on the spatial scale smaller than Southern Ontario and even less data on these very small watersheds that are a part of the MWNS study.

$\mathrm{P}$ stream losses are still small, and farmers are improving $\mathrm{P}$ field applications compared to the 1970's. Application of P does not seem to be exceeding crop needs within Nissouri where 
there is a loss of $-0.47 \mathrm{kgP} \mathrm{ha}^{-1}$ between $\mathrm{P}$ additions and crop removal ignoring stream losses. In Big Creek there is still an over-application of $\mathrm{P}$ of $7.51 \mathrm{kgP} \mathrm{ha}^{-1}$ between additions and crop removal ignoring stream losses. A few new research questions appear from this study by introducing new ideas. Such as will future management of $\mathrm{P}$ application to fields help solve the eutrophication problems in Lake Erie and other waterbodies? Could the current and future P entering streams and the Great Lakes come from watersheds with legacy P storages within the soils? Legacy $\mathrm{P}$ in soils arises because the application of $\mathrm{P}$ to soil can occur much more rapidly than the decline of $\mathrm{P}$ from crop uptake. $\mathrm{P}$ is able to accumulate in soils and be remobilized or recycled, acting as a persistent source to downstream water bodies for decades and centuries (McDowell et al., 2002). A large amount of legacy $\mathrm{P}$ is released into streams by erosional processes (Sharpley et al., 2013). Legacy P strongly correlates with DRP and runoff of soils into streams (Sharpley et al., 2013). Sharpley et al. (2013) looked at the Maumee Watershed where TP concentrations decreased 86\%, between 1975 and 1995. After 1995 P concentrations increased, where the increase of $\mathrm{P}$ to the lakes can be attributed to several factors with the main causes: a buildup of $\mathrm{P}$ at the soil surface with conversion to no-till cropping and increased applications of fertilizer and manure without incorporation in the fall and winter (Joosse and Baker, 2011; Sharpley et al., 2013).

This study showed that $\mathrm{P}$ losses to the stream are a small part of the overall $\mathrm{P}$ balance. It is important to look at the effects of legacy $\mathrm{P}$ on the overall loss of $\mathrm{P}$ to the lakes. It is difficult to know if improvements to the $\mathrm{P}$ balance will lead to lower amounts of $\mathrm{P}$ entering the Great Lakes. There could be other cofounding factors as well such as increases in precipitation, incidental losses, the buildup of legacy $\mathrm{P}$, or it could be just the excess $\mathrm{P}$ that is being applied. More research is needed to look at these other factors. This study is a proof of concept of comparing historical 
and present-day survey data to look at the differences in the P balance of a watershed between two different time periods. As well this study will be completed in all of the remining MWNS watersheds to better compare similarities and differences between all eleven studied watersheds.

\subsection{Limitations of this Study}

There are a few limitations within this study which will be discussed further. The first and an important limitation of this study is the difficulty in validating the calculated numbers such as fertilizer application rates and livestock stocking rates when there is not any similar information at as small of a scale as this study.

The determination of the unknown fields within Big Creek and Nissouri Creek watersheds was another limitation in this study. The AAFC Annual Crop Inventory Data has a published overall accuracy of $85-91 \%$ for the years that we used, and the spatial resolution of the data is 30 $\mathrm{m}^{2}$ (AAFC, 2019). There is a possibility that some of our unknown fields were misclassified using the crop inventory data. There was also some fuzziness in classifications for a few of the smaller fields. Another assumption made was that using the AGRI-Model data the average fertilizer the farmers applied to their fields can correspond to the unknown fields of the same crops within the watersheds. It was seen within the survey data that there was a range of application amounts for the same crop types among different farmers. From taking an average for just over half the watershed and applying it to the remaining crops there could be and under or over estimation of the amount of fertilizer applied to all the fields. A similar approach was also used for the calculation of manure nutrients. Using the AGRI-Model survey data the average of the known barn occupancy rates for different livestock was taken and applied to barns with unknown livestock numbers, this can be a bit unpredictable with some farmers not always stocking the same livestock 
rates as other farmers, where some farmers give more or less space for their livestock than other farmers. All excreted manure within the watersheds was also assumed to stay within the borders of the Nissouri Creek or Big Creek watersheds. Sharpley (2006) stated that manure is not typically transported more than 16 kilometers from the point of generation.

Another study limitation was the assumption of the crop $\mathrm{P}$ removal coefficients of the harvested biomass used in the calculations remained constant between the 1974 - 1975 time period and the 2015 - 2018 time period. There is no determination if the crop P removal coefficients have changed across multiple decades. There could possibly be a change of the crop P removal values used, which were calculated in the early 1990's, as well they were given in a range so both low and high removal values were calculated, and the average was the reported value in this report.

An important point to make is this study looks at the total $\mathrm{P}$ applied within the watersheds and does not differentiate the amount of plant available $\mathrm{P}$ and non-plant available $\mathrm{P}$. Soil $\mathrm{P}$ is always higher than plant available P (Hou et al., 2018). There are a range of factors that control soil $\mathrm{P}$ plant availability such as sorption/desorption, precipitation/dissolution, immobilization/mineralization, weathering, and solid-phase P transformations (Vitousek et al., 2010).

This study also did not look at any Best Management Practices including the 4R's which relates to fertilizer application. The 4R's stand for: the Right source, the Right rate, the Right place, and the Right time. The $4 \mathrm{R}$ 's can help determine if fertilizer application is properly managed. The goal of the $4 \mathrm{R}$ program is to match nutrient supply with crop requirements and to minimize nutrient losses from fields. Best Management Practices are more of a recent agricultural method presently than past years. This could show if farmers are better applying fertilizer to farm fields than during earlier time periods. 


\section{Conclusion}

This study conducted a comprehensive "then and now" assessment of land use and management activities in two watersheds, from information on cropping, livestock numbers, and manure/nutrient applications. This study also completed a P soil balance for two watersheds and compared the two in a "then and now analysis" between the 1970's and the 2010's. This study looked at fertilizer applications, manure applications, crop removals, and stream losses of phosphorus within two watersheds over two time periods separated by $\sim 40$ years.

From 2015 to 2018 in Big Creek and Nissouri Creek changes in landcover were observed compared to the 1970's. The majority of the landcover crop change came from the establishment of the principle cash crop rotation of corn, soybeans, and wheat. There was an observed increase in both stream losses and crop P removal for both Big Creek and Nissouri Creek watersheds. The amount of livestock and in turn manure excretion increased between the 1974 - 1976 time period and the 2015 - 2018 time period. Fertilizer P application rates have decreased in Nissouri Creek since the 1974 - 1976 time period, which is in agreement with other studies. However, there was an observed increase in fertilizer P applications in Big Creek, which does not correspond with previous studies that have looked at Ontario as a whole.

In Nissouri Creek during the 1974 - 1976 time period there was an accumulation of $\mathrm{P}$ within the watershed of approximately $14.84 \mathrm{kgP} \mathrm{ha}^{-1}$, presently averaged for the years of $2015-$ 2018 there was a depletion of $\mathrm{P}$ within the watershed of $-2.19 \mathrm{kgP} \mathrm{ha}^{-1}$. While in Big Creek, during the 1974 - 1976 time period the accumulation of $\mathrm{P}$ within the watershed was $5.29 \mathrm{kgP} \mathrm{ha}^{-1}$, presently averaged for the years 2015 - 2018 there is still an accumulation of $\mathrm{P}$ within the watershed of $4.77 \mathrm{kgP} \mathrm{ha}^{-1}$ of agricultural land. In both watersheds there was a decrease in overall P between the 1974 - 1976 time period and the 2015 - 2018 time period. This study showed 
watershed wide $\mathrm{P}$ balances are important at showing the trends in crop $\mathrm{P}$ removals. A watershed wide $\mathrm{P}$ balance can indicate where there may be storages of $\mathrm{P}$ in different watersheds or depletions of P. This study showed that the P balance may not be the same across all watersheds located within Southern Ontario. Another implication of this study is that stream losses are low and have not significantly increased between the 1970's and the 2010's, there is a high degree of probability that other factors outside of this $\mathrm{P}$ balance are attributing to the recent increases of eutrophication in the Great Lakes. 


\section{$\underline{\text { Appendices }}$}

\section{Appendix A. AGRI-Model Survey Response Sheets.}

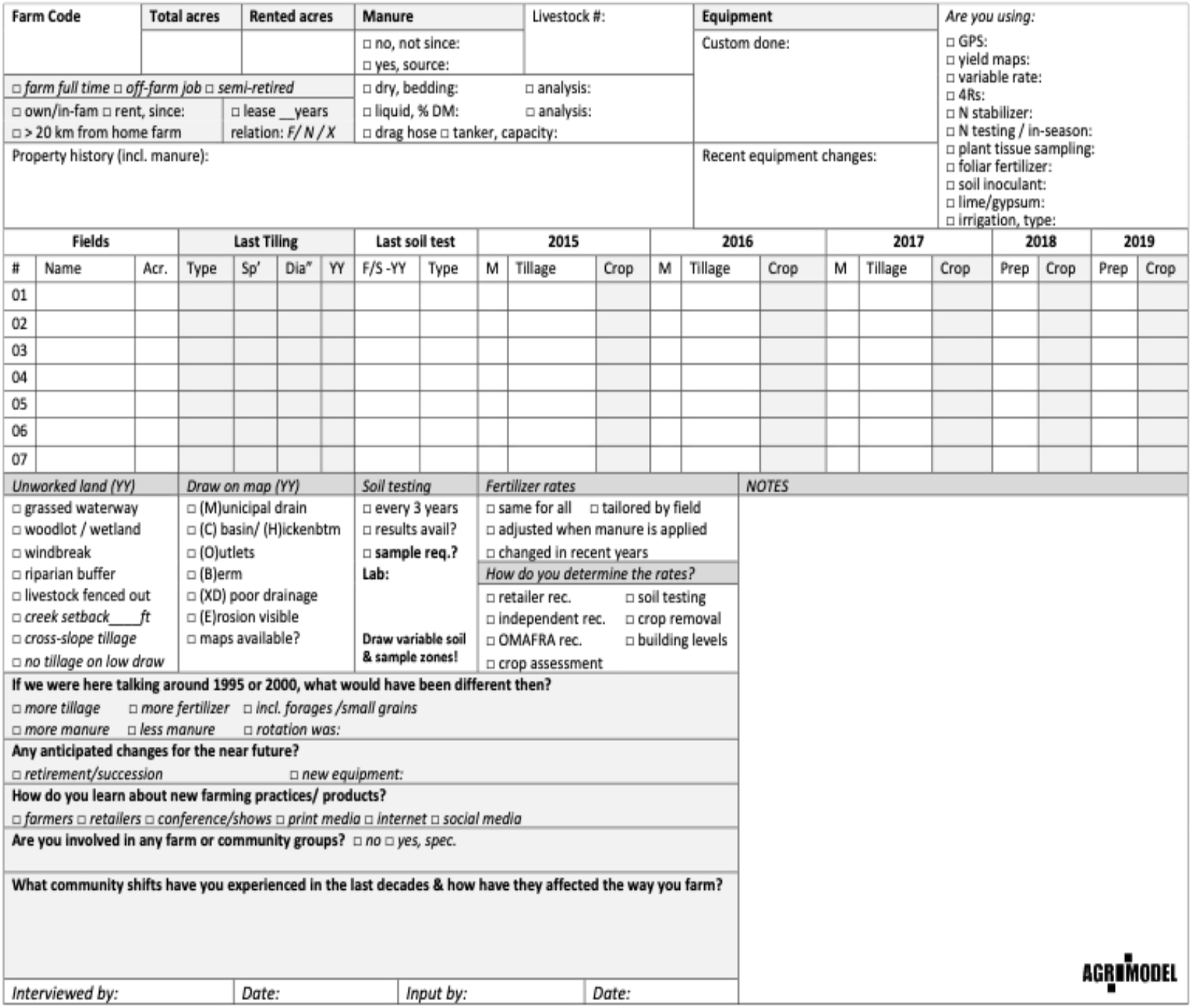




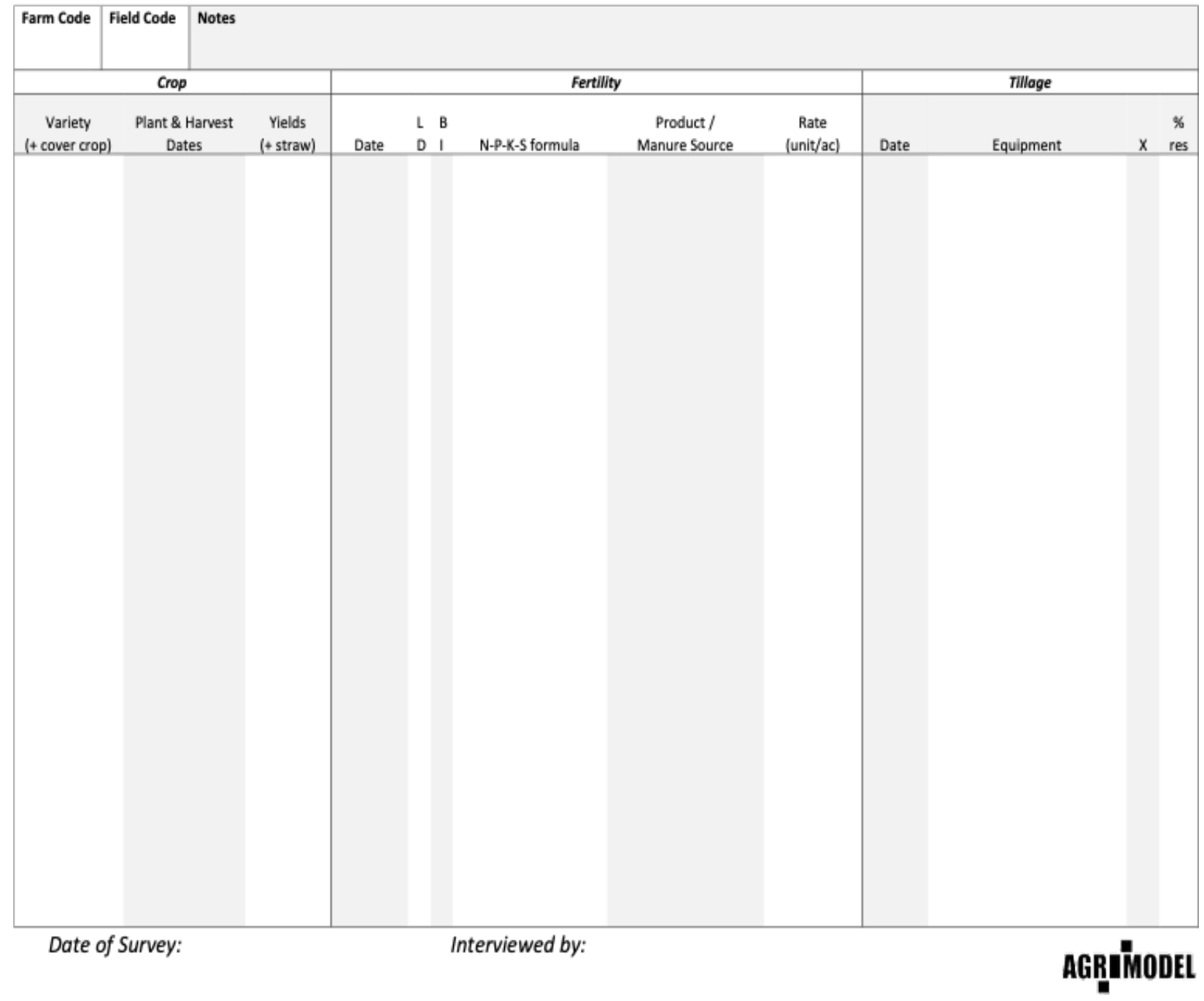




\section{Appendix B. PLUARG Survey Response Sheets.}

O.M.A.F. - I.J.C. QUESTIONNAIRE

Faraer's Name

Farm Number

tot Conc.

Tounship

County

Watershed AS-

Totsl Acres on Fara (In Watershed)

1. CROP AND PLANT FOOD INFORMTION

\begin{tabular}{|c|c|c|c|c|c|c|c|c|c|c|c|c|c|c|c|c|}
\hline \multicolumn{2}{|c|}{$\begin{array}{l}\text { Crops llarvested } \\
\text { (Include Woodlot \& Pasture) }\end{array}$} & \multirow{2}{*}{$\begin{array}{l}\text { Crop } \\
\text { Residue } \\
\mathrm{B}, \mathrm{G}, \mathrm{I}, \mathrm{R}\end{array}$} & \multicolumn{2}{|c|}{ LASD PREPARATION } & \multicolumn{4}{|c|}{$\begin{array}{c}\text { MUNTCIPAL. } \\
\text { MANURE (M) \& SLUDGE (S) }\end{array}$} & \multicolumn{4}{|c|}{$\begin{array}{l}\text { FALL. AND/OR SPRING } \\
\text { FRF-PLANT ANDD/OR } \\
\text { PLANTING FERTILIZER }\end{array}$} & \multicolumn{4}{|c|}{$\begin{array}{l}\text { AFTER PLANTING } \\
\text { TOP DRESSING } \\
\text { SIDE DRESSINC: } \\
\text { MINOR ELERENTS, ETC. }\end{array}$} \\
\hline Name & Acres & & 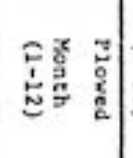 & 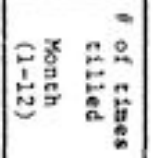 & 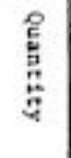 & 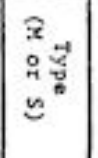 & 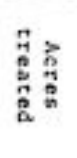 & 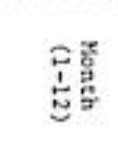 & 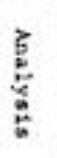 & 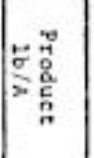 & 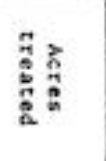 & 家 & 豈 & 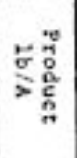 & 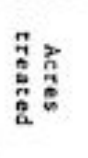 & 它 \\
\hline \multicolumn{17}{|l|}{1.} \\
\hline \multicolumn{17}{|l|}{2.} \\
\hline \multicolumn{17}{|l|}{3.} \\
\hline \multicolumn{17}{|l|}{4.} \\
\hline \multicolumn{17}{|l|}{ s. } \\
\hline \multicolumn{17}{|l|}{6.} \\
\hline \multicolumn{17}{|l|}{7.} \\
\hline \multicolumn{17}{|l|}{8.} \\
\hline $\begin{array}{l}\text { 8. - Burned } \\
\text { 6 : Green Manure } \\
\text { 1. - Incorporated } \\
\text { R. - Removed }\end{array}$ & & & & $\begin{array}{l}\text { Note } \\
\text { Linestone } \\
\text { Irrigat Ion } \\
\text { (Source }\end{array}$ & on $\mathrm{x}$ & $\begin{array}{l}\text { lonth - } \\
\text { de to }\end{array}$ & $\begin{array}{l}09 / 1 \\
\text { es } \\
a\end{array}$ & $\begin{array}{l}\text { to } 08 / \\
\text { ren of } \\
\text { crop }\end{array}$ & $\frac{\text { (cr }}{\text { rop }}$ & $\begin{array}{r}\text { ops) at } \\
-\quad \text { appl } \\
\end{array}$ & $\begin{array}{r}\text { cattons } \\
\text { appl1 } \\
\text { appli }\end{array}$ & $\begin{array}{l}\text { Cons/A } \\
\text { cattons } \\
\text { cations }\end{array}$ & & & & \\
\hline
\end{tabular}


2. CROP PEST COHTROL INFORUTION

\begin{tabular}{|c|c|c|c|c|c|c|}
\hline $\begin{array}{l}\text { A. INSECT \& NFMATODE CONTROL } \\
\text { Trade or Comon Haze }\end{array}$ & Honth & $\begin{array}{l}\text { Foraulation } \\
\text { and Concentration }\end{array}$ & $\begin{array}{l}\text { U.S. } \\
\text { or } \\
\text { Inp. }\end{array}$ & $\begin{array}{l}\text { Rate of applic. } \\
1 \mathrm{~b} \text {. or } \mathrm{Gai} / \mathrm{A}\end{array}$ & $\begin{array}{l}\text { Crops Sprayed (1ncluding Soll } \\
\text { NAHE }\end{array}$ & $\begin{array}{l}\text { Treatment) } \\
\text { ACRES }\end{array}$ \\
\hline \multicolumn{7}{|c|}{1.} \\
\hline \multicolumn{7}{|c|}{2.} \\
\hline \multicolumn{7}{|c|}{3.} \\
\hline \multicolumn{7}{|l|}{4.} \\
\hline $\begin{array}{l}\text { 3. DISEASE CONTROL } \\
\text { Trade or Common Name }\end{array}$ & Month & $\begin{array}{l}\text { Formulation } \\
\text { and Concentration }\end{array}$ & $\begin{array}{l}\text { U.S. } \\
\text { ox } \\
\text { Imp. }\end{array}$ & $\begin{array}{l}\text { Rate of appl1e. } \\
1 \mathrm{~b} \text {. or } \mathrm{Ga1} / \mathrm{A}\end{array}$ & $\begin{array}{l}\text { Crops Sprayed (Including Soll } \\
\text { NAME }\end{array}$ & $\begin{array}{l}\text { Treatment) } \\
\text { ACRES }\end{array}$ \\
\hline \multicolumn{7}{|c|}{1.} \\
\hline \multicolumn{7}{|c|}{2.} \\
\hline \multicolumn{7}{|c|}{3.} \\
\hline \multicolumn{7}{|l|}{4.} \\
\hline $\begin{array}{l}\text { C. WEED CONTROL } \\
\text { Trade or Coman Naee }\end{array}$ & Month & $\begin{array}{l}\text { Formulation } \\
\text { and Concentration }\end{array}$ & $\begin{array}{l}\text { U.S. } \\
\text { or } \\
\text { Inep. }\end{array}$ & $\begin{array}{l}\text { Rate of applic. } \\
\text { 1b. or Gal/h }\end{array}$ & $\begin{array}{l}\text { Crops Sprayed (Including Soll } \\
\text { NAME }\end{array}$ & $\begin{array}{c}\text { Treatment on Fence Rows } \\
\text { ACRES }\end{array}$ \\
\hline \multicolumn{7}{|c|}{1.} \\
\hline \multicolumn{7}{|c|}{2.} \\
\hline \multicolumn{7}{|c|}{3.} \\
\hline \multicolumn{7}{|c|}{4.} \\
\hline \multicolumn{7}{|c|}{5.} \\
\hline \multicolumn{7}{|c|}{6.} \\
\hline \multicolumn{7}{|l|}{7.} \\
\hline \multicolumn{7}{|c|}{8.} \\
\hline \multicolumn{7}{|l|}{9.} \\
\hline 10. & & & & & & \\
\hline
\end{tabular}


3. LIVES2OCK INFONUTION

Anfmals Housed on an Annual Basis, Average Humber

Dalry cows, allkers followers

Beef cows

Sheep (Ewes)

Laying hens

Horses

Swine - farrowing sows and boars

\section{WATER SUPPLY FOR LIVESTOCK}

1. Streas or ditch

2. Fond

3. Hell

4. Munfelpal

5. Coments on vater supply system

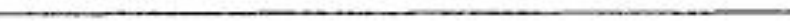

Market Animals, Number Harketed Annually (1975)

Beef feederg (gain 400 to 1100 1bs.)

Beef feeders ( $8 \mathrm{ain} 400$ to $750 \mathrm{bg}$. )

Beef feeders (gain 750 to 1100 1bs.)

Feeder hogs

Chtcken brollers or roasters

Turkey broflers

Heavy turkey hens

lleavy turkey tons

Veal calves

Pullets

Sheep (1ambs)

5. PFSTICIDE USE ON LIVESTOCK

\begin{tabular}{|l|l|l|}
$\begin{array}{c}\text { Formulation } \\
\text { (Nane \& Concentration) }\end{array}$ & $\begin{array}{c}\text { Tyge } \\
\text { Application }\end{array}$ & $\begin{array}{c}\text { Nuber of Applic. } \\
\text { per year }\end{array}$ \\
\hline 1. & & \\
\hline 2. & & \\
\hline 3. & & \\
\hline 4. & & \\
\hline
\end{tabular}


SPECINL INFONMTION

A. History - Activity 1955-1975

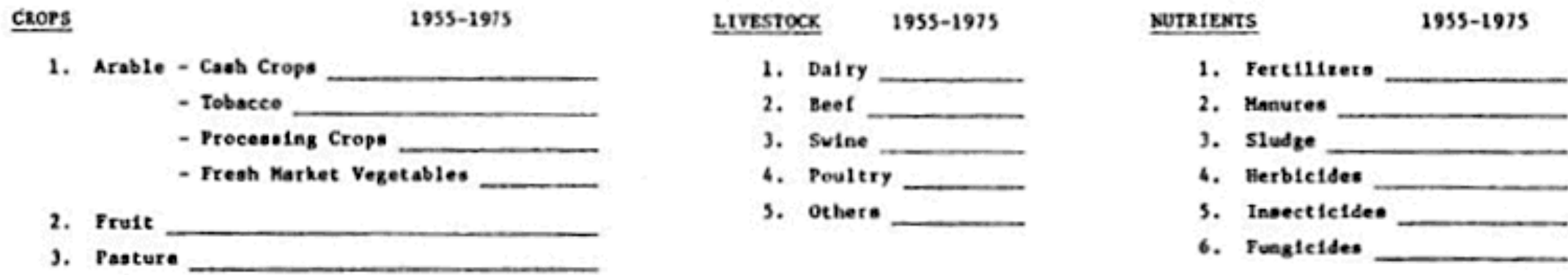

B. conernits -

\begin{tabular}{|c|c|c|c|c|c|c|}
\hline$\underline{A G-13}$ & Use of Triaxines is 1973-76 & 1972 & & & 1974 & \\
\hline & Crop & $1 \mathrm{~b} / \mathrm{A}$ & Acten & Crop & $1 \mathrm{~b} / \mathrm{A}$ & I. Acreal \\
\hline & Atrazine (Aatrex) & & & & & \\
\hline & Petriburia (Sencer) & & & & & \\
\hline & Prometryn (Gesagard) & & & & & \\
\hline & Cyanazine (Bledex) & & & & & \\
\hline & Plasine (Princep) & & & & & \\
\hline & Fianine - Atrasine (Ekko) & & & & & \\
\hline
\end{tabular}




\section{Appendix C. Supplementary Livestock Count and Manure Tables.}

Table C1. Total animal counts and animal units in each watershed during the 1974-1976 time period as well as for the 2015-2018 time period. $95 \%$ confidence intervals are shown in brackets for the present day. No confidence intervals were calculated for Nissouri veal and Nissouri chickens due to $N=1$.

\begin{tabular}{|c|c|c|c|c|c|c|c|c|}
\hline & \multicolumn{9}{|c|}{ Big Creek } & \multicolumn{4}{c|}{ Nissouri Creek } \\
\hline Livestock & $\begin{array}{c}1974- \\
1976 \\
(\text { count })\end{array}$ & $\begin{array}{c}1974- \\
1976 \\
\text { (Animal } \\
\text { Units) }\end{array}$ & $\begin{array}{c}2015-2018 \\
\text { (count) }\end{array}$ & $\begin{array}{c}2015-2018 \\
\text { (Animal } \\
\text { Units) }\end{array}$ & $\begin{array}{c}1974- \\
1976 \\
(\text { count })\end{array}$ & $\begin{array}{c}1974- \\
1976 \\
\text { (Animal } \\
\text { Units) }\end{array}$ & $\begin{array}{c}2015-2018 \\
\text { (count) }\end{array}$ & $\begin{array}{c}2015-2018 \\
(\text { Animal Units) }\end{array}$ \\
\hline Dairy Cattle & 24 & 32 & $263( \pm 212)$ & $356( \pm 287)$ & 1,625 & 1944 & $3,664( \pm 87)$ & $5,132( \pm 118)$ \\
\hline Beef Cattle & 432 & 254 & $931( \pm 82)$ & $820( \pm 72)$ & 1,729 & 1012 & $568( \pm 72)$ & $499( \pm 63)$ \\
\hline Veal Calves & 7 & 2 & $350( \pm 200)$ & $88( \pm 50)$ & 30 & 8 & 250 & 63 \\
\hline Swine & 2,281 & 316 & $1,037( \pm 92)$ & $148( \pm 12)$ & 2,619 & 316 & $14,838( \pm 411)$ & $2153( \pm 44)$ \\
\hline Chickens & 3,425 & 13 & - & - & 161,500 & 358 & 11,989 & 26 \\
\hline Ovine & - & - & - & - & - & - & $319( \pm 76)$ & 64 \\
\hline Turkey & - & - & - & - & - & - & $49,365( \pm 13,947)$ & $737( \pm 104)$ \\
\hline
\end{tabular}


Table C2. This table shows Pounds of P per total amount of manure as excreted both before and after losses for both Nissouri Creek and Big Creek Watersheds. 95\% confidence intervals are shown in brackets for the present day. No Uncertainties were calculated for Nissouri veal and Nissouri chickens due to $N=1$. *After losses pounds of $P$ for manure of ovine, were unable to be calculated thus as excreted numbers were used.

\begin{tabular}{|c|c|c|c|c|c|c|c|c|}
\hline & \multicolumn{4}{|c|}{ Big Creek } & \multicolumn{4}{|c|}{ Nissouri Creek } \\
\hline Livestock & $\begin{array}{c}1974- \\
1975 \\
\text { Plb/ton } \\
\text { as } \\
\text { Excreted }\end{array}$ & $\begin{array}{c}1974- \\
1975 \\
\text { Plb/ton } \\
\text { After } \\
\text { Losses }\end{array}$ & $\begin{array}{c}2015-2018 \\
\text { Plb/ton as } \\
\text { Excreted }\end{array}$ & $\begin{array}{c}\text { 2015-2018 } \\
\text { Plb/ton After } \\
\text { Losses }\end{array}$ & $\begin{array}{c}1974- \\
1975 \\
\text { Plb/ton } \\
\text { as } \\
\text { Excreted }\end{array}$ & $\begin{array}{c}1974- \\
1975 \\
\text { Plb/ton } \\
\text { After } \\
\text { Losses }\end{array}$ & $\begin{array}{c}2015-2018 \\
\mathrm{Plb} / \text { ton as } \\
\text { Excreted }\end{array}$ & $\begin{array}{c}\text { 2015-2018 } \\
\text { Plb/ton After } \\
\text { Losses }\end{array}$ \\
\hline Dairy Cattle & 877 & 754 & $\begin{array}{c}11,743 \\
( \pm 9,474)\end{array}$ & $\begin{array}{c}10,092 \\
( \pm 8,142)\end{array}$ & 40,857 & 34,932 & $\begin{array}{c}163,708 \\
( \pm 3,904)\end{array}$ & $\begin{array}{c}140,687 \\
( \pm 3,355)\end{array}$ \\
\hline Beef Cattle & 8,401 & 7,130 & $\begin{array}{c}32,986 \\
( \pm 2,897) \\
\end{array}$ & $\begin{array}{c}27,998 \\
( \pm 2,458) \\
\end{array}$ & 33,398 & 28,343 & $\begin{array}{c}19,671 \\
( \pm 2,454) \\
\end{array}$ & $\begin{array}{c}16,732 \\
( \pm 2,091) \\
\end{array}$ \\
\hline Veal Calves & 43 & 36 & $\begin{array}{c}2,608 \\
( \pm 1,491)\end{array}$ & $\begin{array}{c}2,216 \\
( \pm 1,267)\end{array}$ & 183 & 155 & $\begin{array}{l}1,863 \\
( \pm 0) \\
\end{array}$ & $\begin{array}{l}1,583 \\
( \pm 0)\end{array}$ \\
\hline Swine & 12,237 & 10,403 & $\begin{array}{c}6,517 \\
( \pm 586)\end{array}$ & $\begin{array}{c}5,537 \\
( \pm 499)\end{array}$ & 13,311 & 11,324 & $\begin{array}{c}99,108 \\
( \pm 2,445)\end{array}$ & $\begin{array}{c}84,232 \\
( \pm 2,026)\end{array}$ \\
\hline Chickens & 71 & 60 & - & - & 38,615 & 32,727 & $\begin{array}{l}3,477 \\
( \pm 0)\end{array}$ & $\begin{array}{c}2,946 \\
( \pm 0)\end{array}$ \\
\hline Ovine & - & - & - & - & - & - & $\begin{array}{c}2,389 \\
( \pm 569)\end{array}$ & $\begin{array}{c}2,389 \\
( \pm 569)\end{array}$ \\
\hline Turkey & - & - & - & - & - & - & $\begin{array}{c}91,042 \\
( \pm 12,861)\end{array}$ & $\begin{array}{c}77,420 \\
( \pm 10,936)\end{array}$ \\
\hline Total Amount & 21,629 & 18,383 & $\begin{array}{c}53,854 \\
( \pm 10,036)\end{array}$ & $\begin{array}{c}45,843 \\
( \pm 8,613)\end{array}$ & 126,364 & 107,481 & $\begin{array}{c}381,258 \\
( \pm 13,891)\end{array}$ & $\begin{array}{c}325,989 \\
( \pm 11,817)\end{array}$ \\
\hline
\end{tabular}




\section{References}

Agriculture and Agri-Food Canada [AAFC]. (Multiple: 2015...2018). Annual Crop Inventory Data. Retrieved from: https://open.canada.ca/data/en/dataset/ ba2645d5-4458-414d-b196-6303ac06c1c9

Agriculture and Agri-Food Canada [AAFC]. (2019). Annual Crop Inventory - Data Product Specifications. (ISO 19131). Retrieved from https://open.canada.ca/data/en/dataset/ ba2645d5-4458-414d-b196-6303ac06c1c9

Baker, D.B. and Richards, R.P. (2002). Phosphorus Budgets and Riverine phosphorus export in Northwestern Ohio Watersheds. Journal of Environmental Quality, 31, 96-108.

Baker, D.B., Confesor, R., Ewing, D.E., Johnson, L.T., Kramer, J.W., and Merryfield, B.J. (2014). Phosphorus loading to Lake Erie from the Maumee, Sandusky and Cuyahoga rivers: The importance of bioavailability. Journal of Great Lakes Research, 40, 502-517.

Bast, L., Mullen, R., O'Halloran I., Warncke D., and Bruulsema, T. (2009). Phosphorus Balance Trends on Agricultural Soils of the Lake Erie Drainage Basin. Better Crops, 93(1), 6-8.

Bruulsema, T.W., Mullen, R.W., Ohalloran, I.P., and Warncke, D.D. (2011). Agricultural phosphorus balance trends in Ontario, Michigan and Ohio. Canadian Journal of Soil Science, 91(3), 437-442. 
Bruulsema T.W. (2016). Soil phosphorus trends in the Lake Erie region. Better Crops, 100, 4-6.

Chambers, P.A., Vis, C., Brua, R.B., Guy, M., Culp, J.M., and Benoy, G.A. (2008). Eutrophication of agricultural streams: Defining nutrient concentrations to protect ecological condition. Water Science and Technology, 58, 2203-2210.

Dolan, D.M. (1993). Point source loadings of phosphorus to Lake Erie: 1986-1990. Journal of Great Lakes Research, 19, 212-223.

Frank, R., Ripley, B.D. (1977). Land use activities in eleven agricultural watersheds in southern Ontario, Canada, 1975-76, PLUARG. Guelph, Ontario.

Great Lakes Water Quality Agreement [GLWQA].(1972). Great Lakes Water Quality Agreement, signed April 15, 1972.

Great Lakes Water Quality Agreement [GLWQA] Nutrients Annex Subcommittee. (2015). Recommended Phosphorus Loading Targets for Lake Erie.

Han, H., Allan, J. D., and Bosch, N. S. (2012). Historical pattern of phosphorus loading to Lake Erie watersheds. Journal of Great Lakes Research, 38(2), 289-298

Hofmann, N. (2008). A Geographical Profile of Livestock Manure Production in Canada, 2006. EnviroStats, 2(4), 12-16. 
Hou, E., Tan, X., Heenan, M., and Wen, D. (2018). A global dataset of plant available and unavailable phosphorus in natural soils derived by Hedley method. Scientific Data, 5, 180166.

Howard, A.E., Olson, B.M., and Cooke. S.E. (2006). Impact of soil phosphorus loading on water quality in Alberta: A review. 41 pp. In Alberta Soil Phosphorus Limits Project. Volume 5: Background information and reviews. Alberta Agriculture, Food and Rural Development, Lethbridge, Alberta, Canada.

International Joint Commission [IJC]. (2018). Fertilizer Application Patterns and Trends and Their Implications for Water Quality in the Western Lake Erie Basin.

International Reference Group on Great Lakes Pollution from Land Use Activities [PLUARG]. (1974). Detailed Study Plan to Assess Great Lakes Pollution from Land Use Activities.

International Reference Group on Great Lakes Pollution from Land Use Activities [PLUARG]. (1978). Environmental Management Strategy for The Great Lakes System. Final Report to The International Joint Commission. Windsor, Ontario.

Jiao, J., Ellis, E.C., Yesilonis, I., Wu, J., Wang, H., Li, H., and Yang, L. (2009). Distributions of soil phosphorus in China's densely populated village landscapes. Journal of Soils and Sediments 10, 461-472. 
Joosse P.J. and Baker D.B. (2011). Context for Re-Evaluating Agricultural Source Phosphorus Loadings to the Great Lakes. Canadian Journal of Soil Science, 91, 317-327.

Kellogg, R.L., Lander, C.H., Moffitt, D.C. and Gollehon, N. (2000). Manure nutrients relative to the capacity of cropland and pastureland to assimilate nutrients: Spatial and temporal trends for the United States. USDA-NRCS-ERS Publication No. nps00-579.

King K.W., Williams M.R., Johnson L.T., Smith D.R., Labarge G.A., and Fausey N.R. (2017). Phosphorus Availability in Western Lake Erie Basin Drainage Waters: Legacy Evidence across Spatial Scales. Journal of Environment Quality, 46(2), 466.

LimnoTech, (2017). Assessment of Fertilizer and Manure Application in the Western Lake Erie Basin. Completed for the International Joint Commission Science Advisory Board's Science Priority Committee. Retrieved from http://ijc.org/files/publications/LimnoTech_IJC_Fertilizer.pdf

McDowell, R.W., Sharpley, A.N., and Chalmers, A.T. (2002). Land use and flow regime effects on phosphorus chemical dynamics in the fluvial sediment of the Winooski River, Vermont. Ecological Engineering. 18:477-487.

Miller, M.H., J.B. Robinson, D.R. Coote, A.C. Spires and D.W. Draper. (1982). Agriculture and water quality in the Canadian Great Lakes basin: II. Phosphorus. Journal of Environmental Quality, 11, 487-493. 
Mohamed, M. (n.d.) MOE Multi-Watershed Nutrient Study. Presentation presented at Ausable Bayfield Conservation Authority.

Obenour, D.R., Gronewold, A.D., Stow, C.A., and Scavia, D. (2014). Using a Bayesian hierarchical model to improve Lake Erie cyanobacteria bloom forecasts. Water Resources Research, 50, 7847-7860.

Ontario Ministry of Agriculture, Farming, and Rural Affairs [OMAFRA]. (2017). Agronomy Guide for Field Crops. (Pub. 811). Toronto, Canada: Queens Printer for Ontario.

Ontario Ministry of the Environment and Climate Change [MOECC]. (2016). Ontario's Great Lakes Strategy 2016 Progress Report. Retrieved from https://www.ontario.ca/page/ontarios-great-lakes-strategy-2016-progress-report/

Parthasarathy, N.S. (1994). Demand forecasting for fertilizer marketing. Food and Agriculture Organization for the United Nations. Rome. Retrieved from http://www.fao.org/3/T4240E/T4240E00.htm

Powers, S.M., Bruulsema, T.W., Burt, T.P., Chan, N.I., Elser, J.J., Haygarth, P.M., Howden, N.J.K., Jarvie, H.P., Lyu, Y., Peterson, H.M., Sharpley, A.N., Shen, J., Worrall, F., and Zhang, F. (2016). Long-term accumulation and transport of anthropogenic phosphorus in three river basins. Nature Geoscience, 9, 353-356. 
Richards, R.P. (1998). Estimation of pollutant loads in rivers and streams: a guidance document for NPS programs. U.S. EPA Region VIII Grant X998397-01-0, Water Quality Laboratory, Heidelberg College, Tiffin, $\mathrm{OH}$.

Richards, R.P. and Baker., D.B. (2002). Trends in water quality in LEASEQ rivers and streams (northwestern Ohio), 1975-1995. Journal of Environmental Quality, 31, 90-96.

Richards, R. P., Baker, D. B. and Crumrine, J. P. (2009). Improved water quality in Ohio tributaries to Lake Erie: A consequence of conservation practices. Journal of Soil Water Conservation, 64, 200-211.

Rosamond, M. S., Wellen, C., Yousif, M. A., Kaltenecker, G., Thomas, J. L., Joosse, P. J., Feisthauer, N.C., Taylor, W. D., and Mohamed, M. N. (2018). Representing a large region with few sites: The Quality Index approach for field studies. Science of the Total Environment, 633, 600-607.

Scavia, D., Allan, J.D., Arend, K.K., Bartell, S., Beletsky, D., Bosch, N.S., Brandt, S.B., Briland, R.D., Daloğlu, I., Depinto, J.V., Dolan, D.M., Evans, M.A., Farmer, T.M., Goto, D., Han, H., Höök, T.O., Knight, R., Ludsin, S.A., Mason, D., Michalak, A.M., Richards, R.P., Roberts, J.J., Rucinski, D.K., Rutherford, E., Schwab, D.J., Sesterhenn, T.M., Zhang, H., and Zhou, Y. (2014). Assessing and addressing the re-eutrophication of Lake Erie: Central basin hypoxia. Journal of Great Lakes Research, 40, 226-246. 
Sharpley, A. (1995). Dependence of runoff phosphorus on extractable soil phosphorus. Journal of Environmental Quality, 24, 920-926.

Sharpley, A. (2006). Agricultural phosphorus management: Protecting production and water quality, lesson 34. (Livestock and Poultry Environmental Stewardship (LPES) Curriculum).

Sharpley, A.N., Jarvie, H.P., Buda, A., May, L., Spears, B., and Kleinman, P. (2013). Phosphorus Legacy: Overcoming the Effects of Past Management Practices to Mitigate Future Water Quality Impairment. Journal of Environmental Quality, 42, 1308-1326

Sonzogni, W.C., Chapra, S.C., Armstrong, D.E., and Logan, T.J. (1982). Bioavailability of phosphorus inputs to Lakes. Journal of Environmental Quality, 11, 555-563.

Sorichetti, R.J., Yousif, M., Thomas, T., Wellen, C., and Mohamad, M. Seasonal shift in nutrient export from agricultural watersheds; a then and now comparison. In preparation for submission to Environmental Science \& Technology Fall 2019.

Statistics Canada. n.d. Estimated areas, yield and production of principal field crops by Small Area Data Regions, in metric and imperial units. (Table 32-10-0002-01). Retrieved July 20, 2019 from Statistics Canada: https://www150.statcan.gc.ca/t1/tbl1/en/tv.action?pid=3210000201 
Statistics Canada. n.d. Cattle and Calves on Census Day. (Table 32-10-0424-01). Retrieved July 20, 2019 from Statistics Canada:

https://www150.statcan.gc.ca/t1/tbl1/en/tv.action?pid=3210042401

Statistics Canada. n.d. Pigs on census day. (Table 32-10-0426-01). Retrieved July 20, 2019 from Statistics Canada: https://www150.statcan.gc.ca/t1/tb11/en/tv.action?pid=3210042601

Taylor, J. R. (1996). An Introduction to Error Analysis, 2nd Ed., Sausalito, CA: University Science Books.

Tin, M. (1965). Comparison of Some Ratio Estimators. Journal of the American Statistical Association, 60(309), 294-307.

Upsdell Wright, B. L., E. J. Wilson, M. Veliz, and I. W. Heathcote. (2015). Proceedings of the Sharing Loading Estimation Experiences Workshop, Guelph, Ontario, January 20, 2015. Ausable Bayfield Conservation Authority, Exeter, Ontario.

van Bochove, E., Denault J.-T., Leclerc, M.-L., Thériault, G., Dechmi, F., Allaire, S. E., Rousseau, A. N. and Drury, C. F. (2011). Temporal trends of risk of water contamination by phosphorus from agricultural land in the Great Lakes Watersheds of Canada. Canadian Journal of Soil Science, 91, 443 
Vitousek, P. M., Porder, S., Houlton, B. Z. and Chadwick, O. A. (2010). Terrestrial phosphorus limitation: mechanisms, implications, and nitrogen-phosphorus interactions. Ecological Applications, 20, 5-15. 